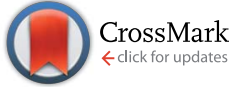

Cite this: RSC Adv., 2016, 6, 99664

Received 19th September 2016

Accepted 8th October 2016

DOI: $10.1039 / c 6 r a 23317 a$

www.rsc.org/advances

\section{Multicomponent synthesis of hydrazino depsipeptides $\uparrow$}

\author{
Josipa Suć, ${ }^{a}$ Danijela Barićb ${ }^{b}$ and Ivanka Jerić ${ }^{\star a}$ \\ The Passerini reaction of $\alpha$-hydrazino acids, carbonyl compounds and isocyanides yielded hydrazino \\ depsipeptides, a new class of backbone extended peptidomimetics comprising amide bond isostere. A \\ wide range of carbonyl and isocyano components were used along the $\alpha$-hydrazino acids carrying three \\ different $N^{\alpha}$ protecting groups. The kinetics and thermodynamic equilibrium of the rate-determining step \\ of the reaction with different $\alpha$-hydrazino acids were studied by DFT approach.
}

\section{Introduction}

Screening of small-molecule libraries has been the most commonly used tool in drug discovery over the past two decades. ${ }^{1}$ However, most libraries lack diversity in terms of biological and chemical properties, i.e. "chemical space" covered is infinitely small. Contrary to that, natural products with complex molecular architectures and numerous stereogenic centers represent valuable pool of drug candidates. ${ }^{2}$ Therefore, access to libraries of natural product-like compounds with high degree of structural diversity is important for development of novel leads needed to tackle new generations of biological targets. ${ }^{3}$

Natural products that contain an $\mathrm{N}-\mathrm{N}$ bond compose of a fascinating group of compounds with a tremendous variety of structures and biological activities. ${ }^{4}$ Among them are compounds that contain $\alpha$-hydrazino acid motif, like antibiotic negamycine, ${ }^{5}$ the $\mathrm{B} 6$ vitamin antagonist linatine ${ }^{6}$ and numerous peptides with embedded cyclic hydrazine skeleton - piperazic acid. ${ }^{7}$ Synthetic hydrazino peptidomimetics show enhanced stability toward proteolytic enzymes and extended pharmacokinetic properties, ${ }^{\mathbf{8}}$ exhibit antimicrobial ${ }^{9}$ and proteasome inhibition activity. ${ }^{10}$ Also, hydrazino peptidomimetics show high propensity toward specific secondary structure known as hydrazino-turn, an eightmembered hydrogen-bonded pseudo-cycles. ${ }^{8}$ Ability to adopt well-defined folded structures is an important feature for various

${ }^{a}$ Division of Organic Chemistry and Biochemistry, Ruđer Bošković Institute, Bijenička cesta 54, 10000 Zagreb, Croatia.E-mail: ijeric@irb.hr

${ }^{b}$ Division of Physical Chemistry, Ruđer Bošković Institute, Bijenička cesta 54, 10000 Zagreb, Croatia

$\dagger$ Electronic supplementary information (ESI) available: Copies of ${ }^{1} \mathrm{H} \mathrm{NMR},{ }^{13} \mathrm{C}$ NMR and ESI-HRMS spectra of products. Cartesian coordinates of minima and transition state for the rate-determining step of the reaction. Cartesian coordinates of non-productive conformers of imidate cluster. Energies, number of imaginary frequences and zero point vibrational energies for minima and transition state for the rate determining step of the reaction. Energies, number of imaginary frequences and zero point vibrational energies for non-productive conformers of imidate cluster. See DOI: 10.1039/c6ra23317a biomedical applications, but also construction of functional materials. Thus, incorporation of only one hydrazino-derivative of trans-2-aminocyclobutanecarboxylic acid caused stabilization of 8-helix over 12-helix conformation for an oligomer length up to 6 residues. ${ }^{11}$ Also, heterochiral cyclic oligomers composed of $1: 1$ mixture of $\alpha$-amino acids and $\alpha$-hydrazino acids self-assemble into nanotubular structures in solution and solid phase. ${ }^{12} \mathrm{We}$ have recently designed a small series of hydrazino peptidomimetics and showed that their interaction with DNA and RNA can be finely modulated with the number and relative position of $\alpha$ hydrazino acid(s) within the peptide chain. ${ }^{\mathbf{1 3}}$

Since wider utilization of hydrazino peptidomimetics depends on easy access to the libraries of compounds, we are interested in developing reliable strategies for fast construction of structurally distinct compounds based on $\alpha$-hydrazino acid motif. Multicomponent reactions (MCRs) offer numerous advantages over traditional sequential reactions for the synthesis of diverse structurally demanding compounds. ${ }^{\mathbf{1 4}}$ MCRs were applied in the synthesis of small drug-like molecule libraries, ${ }^{15}$ but also large and more complex molecules. ${ }^{\mathbf{1 6}}$ Isocyanide-based MCRs, particularly Passerini and Ugi reactions, are of special importance, because they provide peptidelike compounds. ${ }^{14 b, 17}$ The utility of the Passerini reaction relays on the mild reaction conditions required for the condensation of a carbonyl compound, a carboxylic acid and an isocyanide to afford $\alpha$-acyloxycarboxamides - depsipeptides. ${ }^{\mathbf{1 4 b}}$ Many naturally occurring depsipeptides have a wide range of biological activity, ${ }^{\mathbf{1 8}}$ therefore, depsipetides are considered a lead compounds in the drug development process, ${ }^{19}$ but also promising polymers for biomedical applications. ${ }^{20}$ Since backbone structure of the Passerini product is influenced mainly by the carboxylic component, ${ }^{21}$ introduction of $\alpha$-hydrazino acid as a carboxylic component could yield a novel class of peptidomimetics - hydrazino depsipeptides. These peptidomimetics bear two distinct structural features: backbone extension steaming from the hydrazino acid component and amide bond isostere as a result of the Passerini reaction (Scheme 1). 


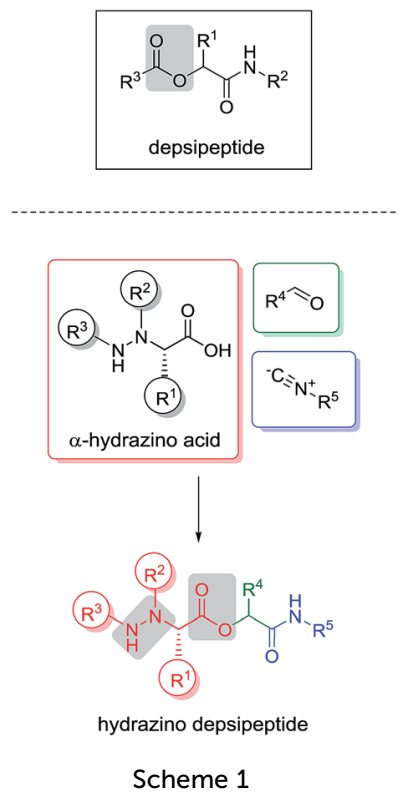

\section{Results and discussion}

$\mathrm{N}$-Terminal position of $\alpha$-hydrazino acid-derived part in the Passerini product (Scheme 1) allows further modification through some other MCR or a standard peptide coupling procedure, therefore three types of $\alpha$-hydrazino acids were used in this study. $N^{\alpha}$-Benzyl, $N^{\beta}$-Boc protected hydrazino acids (type I, Scheme 2) were obtained by electrophilic amination of the corresponding $N$-benzyl-L-amino acid with $N$-Boc oxaziridine. ${ }^{22}$ Nucleophilic substitution of D-amino acid-derived $\alpha$-bromo acid with Boc-hydrazine yielded $N^{\beta}$-Boc protected $\alpha$-hydrazino acids, ${ }^{23}$ where $N^{\alpha}$ position was further protected with Boc (type II) or Cbz group (type III, Scheme 2). ${ }^{24}$ Also, hydrazino proline derivative, Boc-hPro-OH (Scheme 2) was used to explore the utility of cyclic acid components in the Passerini reaction.

In order to introduce $\alpha$-hydrazino acid in the Passerini reaction, we performed a model reaction with $N^{\alpha}$-benzyl, $N^{\beta}$-Boc protected hydrazino-L-leucine, $p$-nitro benzaldehyde and methyl 2-isocyano-3-phenylpropanoate in order to optimize reaction conditions. First reaction performed in dry dichloromethane under argon for $24 \mathrm{~h}$ gave the corresponding Passerini product 1 in $40 \%$ yield (Table 1, Entry 1). Encouraged by this result, we

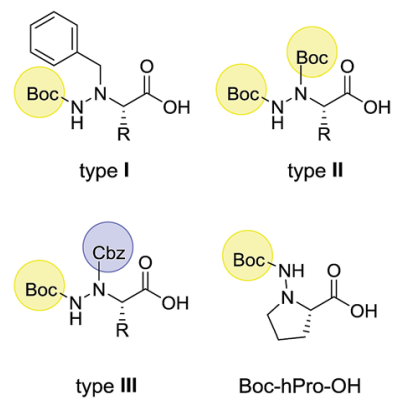

Scheme 2
Table 1 Optimization of the Passerini reaction ${ }^{a}$

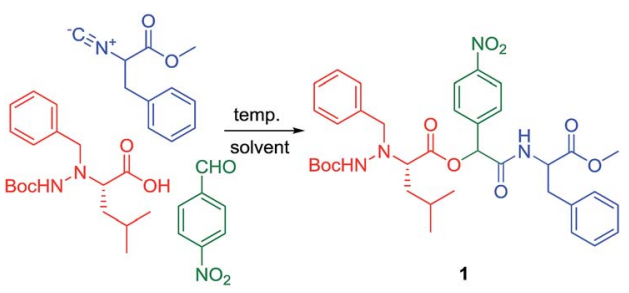

\begin{tabular}{llll}
\hline Entry & Solvent & $T\left[{ }^{\circ} \mathrm{C}\right]$ & Yield $^{b}[\%]$ \\
\hline 1 & Dichloromethane & RT & 40 \\
2 & Ethyl acetate & RT & 33 \\
3 & Tetrahydrofuran & RT & 54 \\
4 & Nitromethane & RT & 38 \\
5 & Tetrahydrofuran & 50 & 42 \\
6 & - & 80 & 31
\end{tabular}

${ }^{a}$ All reactions were carried out in 24 hours with equal amounts of reactants. ${ }^{b}$ Isolated yields.

optimized reaction conditions by testing different solvents and found tetrahydrofurane as the most appropriate solvent for the Passerini reaction (54\%, Entry 3). Performing reaction at $50{ }^{\circ} \mathrm{C}$ in THF failed to improve the yield of $\mathbf{1}$ (Entry 5). Bousquet et al. described a convenient and efficient Passerini multicomponent reaction under solvent-free conditions at high temperature, ${ }^{25}$ therefore, we examined the effect of solvents on the course of the reaction. The solvent-free reaction carried out at $80^{\circ} \mathrm{C}$ gave Passerini product 1 in $31 \%$ yield (Entry 6). Therefore, optimal conditions for the Passerini reaction with $\alpha$-hydrazino acids were THF as a solvent at room temperature for $24 \mathrm{~h}$. With optimized conditions in hand, we set out to test the scope of the protocol with different oxo-compounds, isocyanides and $\alpha$ hydrazino acids.

The Passerini reactions performed with $N^{\alpha}$-benzyl, $N^{\beta}$-Boc protected hydrazino acids (I) furnished corresponding Passerini products in $22-74 \%$ yields (Table 2, products 1-12). It is known that the nature of an oxo-component (aldehyde/ketone) have significant impact on the outcome of the Passerini reactions. Comparison of the Passerini reactions performed with $p-\mathrm{NO}_{2}$ benzaldehyde (products 1, 2, 5 and 9), benzaldehyde (product 6) and $p$-Cl benzaldehyde (10) revealed that aromatic aldehydes bearing electron withdrawing substituent furnished corresponding products in moderate to very good yields (36-63\%), compared to unsubstituted aldehyde $6(22 \%)$, while no product was obtained with aldehyde bearing electron donating substituents. Reactions performed with aliphatic aldehyde 2-methylpentanal (compounds 3, 4, 11 and 12) gave Passerini products in $21-74 \%$ yields, indicating that reaction is also strongly influenced by the nature of acid and isocyano-component. Finally, two ketones were used in the Passerini reaction; product 7 was obtained with acetone in fair yield (42\%), while acetophenone failed to give the expected product 8. Generally, lower yields were obtained with commercially available isocyanides (compounds $4, \mathbf{9}, \mathbf{1 2}$ ) than with amino acid-derived 
Table 2 Scope of the protocol for the synthesis of hydrazino depsipeptides ${ }^{a}$

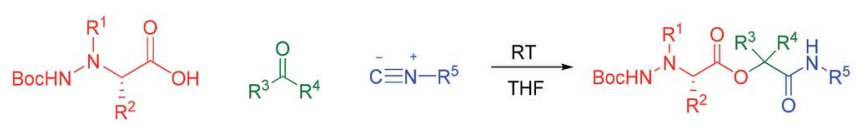
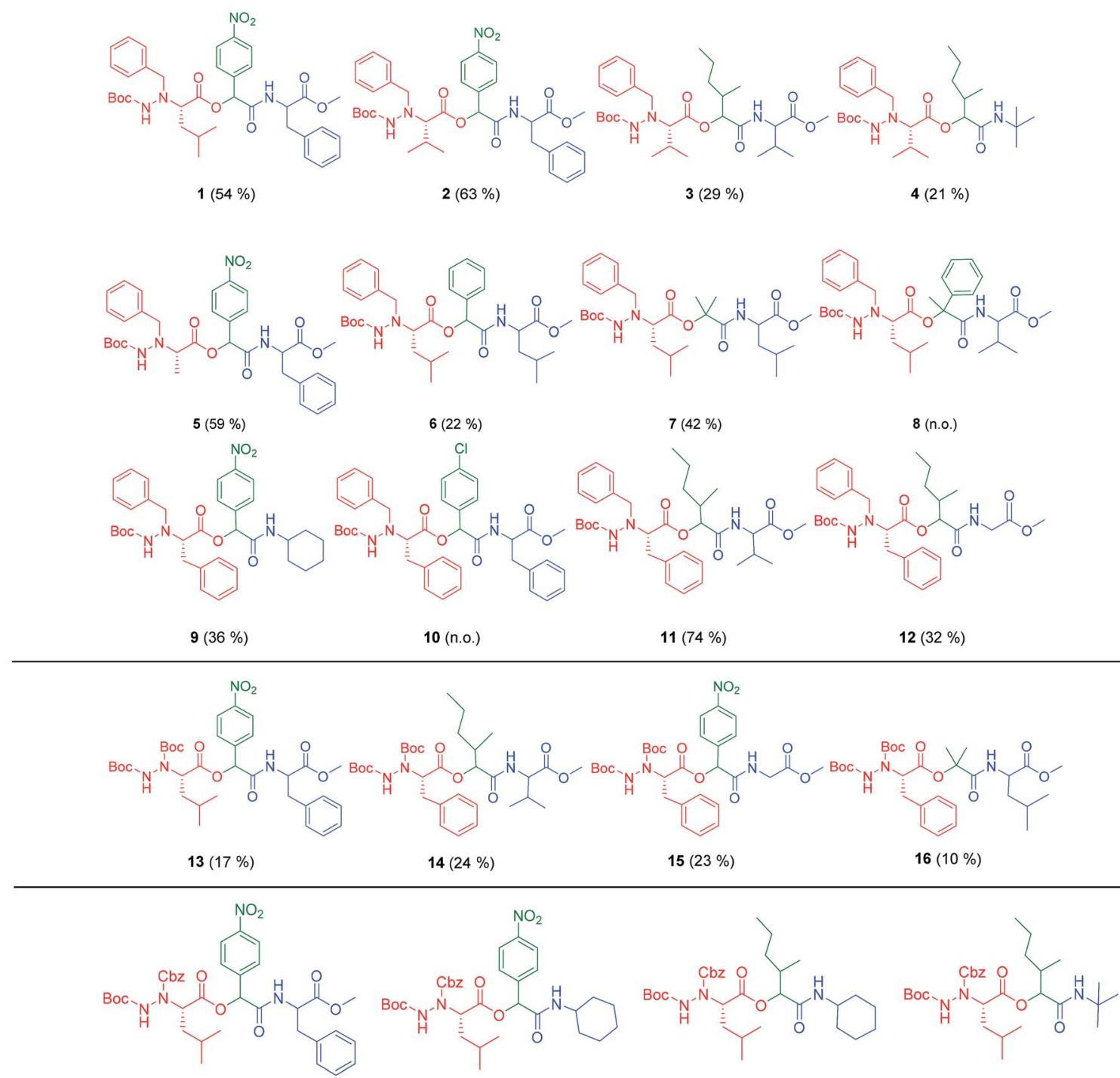

$17(11 \%)$

$18(55 \%)$

$19(27 \%)$

$20(32 \%)$

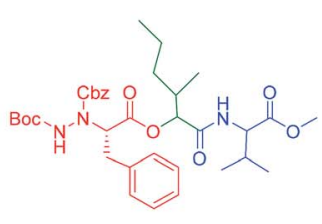

$21(54 \%)$

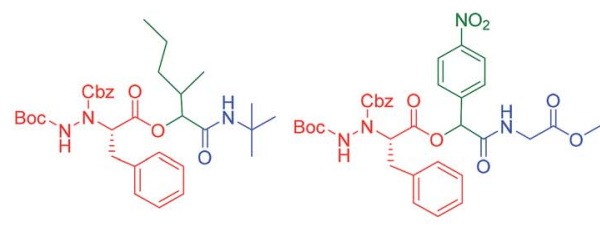

$22(43 \%)$

$23(32 \%)$

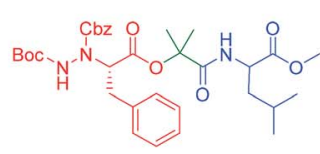

24 (n.o.)

${ }^{a}$ Isolated yields are given in parentheses. Compounds were isolated as mixture of diastereoisomers. n.o. - not obtained.

ones. Also, amino acid side-chain group seems to have low impact on the reactivity in the Passerini reaction.

Next, we tested reactions with type II $\alpha$-hydrazino acids, namely leucine- and phenylalanine-related $N^{\alpha}$-Boc, $N^{\beta}$-Boc protected derivatives. Reactions were performed with $p-\mathrm{NO}_{2}$ benzaldehyde, and 2-methylpentanal or acetone as oxocomponents in the presence of amino acid-derived isocyanides. Regardless oxo- and isocyano-components used, 
products 13-16 were obtained in low yields (10-24\%, Table 2). The utility of $N^{\alpha}$-Cbz, $N^{\beta}$-Boc protected hydrazino acids (type III) in the Passerini reaction was tested with the same set of oxocompounds and various isocyanides, yielding hydrazino depsipeptides 17-24 (Table 2). Passerini products with type III hydrazino acids are obtained in generally higher yields than with type II hydrazino acids (11-55\%). It is interesting to note, that two products isolated in highest yield, 18 and 21, are assembled of all three different components.

Finally, the success of the protocol prompted us to test its scope with $N^{\beta}$-Boc protected hydrazino proline. Because of the low reactivity of ketones observed in previous reactions, Passerini reactions were performed only with aldehydes. The corresponding products were isolated in low yields (25-28, Table 3 ), with the exception of $p-\mathrm{NO}_{2}$ benzaldehyde/cyclohexyl isocyanide combination which yielded the Passerini product 26 in $55 \%$ yield.

Comparison of obtained results revealed that efficiency of hydrazino acids in the Passerini reaction decreases in line: type $\mathbf{I}>$ type III > type II. The best examples are Passerini products $11(74 \%)-21(54 \%)-14(24 \%)$ and also $1(54 \%)-17$ (11\%) - 13 (17\%), where type II hydrazino acid afforded Passerini product is slightly better yield than type III hydrazino acid, but type I hydrazino acid-related Passerini product is obtained in by far better yield. Possible explanation for such outcome can be find in steric hindrance of $\mathrm{Cbz}$ and especially Boc group at the $N^{\alpha}$ atom, but also different nature of substituent; $N$-benzyl $v s$. urethane type of bond. To investigate the disparity in a yield of products obtained by different hydrazino acids, we decided to get insight into reaction mechanism. An extensive research has been devoted to elucidate the mechanism of the Passerini reaction, ${ }^{\mathbf{1 4 c , 1 7 b , 2 6}}$ including the theoretical approach by DFT methods in a paper of Maeda et $a l .{ }^{27}$ Using the simplest set of reactants (formaldehyde, methyl isocyanide and formic acid) and calculating energies of all possible stationary points for the reaction at M0628/6-31G(d,p) + ZPE level of theory ${ }^{28}$ it was found that the most productive mechanism in gas phase consists of seven steps: formation of $\mathrm{H}$-bonded cluster between acid and aldehyde (1), followed by reaction with isocyanide (2) that results in occurrence of imidate (3). Imidate then forms $\mathrm{H}$-bonded cluster with additional molecule of acid that serves as a catalyst (4), enabling rearrangement of this cluster with imidate to dioxolane intermediate (5) stabilized by $\mathrm{H}$-bonds with additional acid molecule. Conformational change of $\mathrm{H}$-bonded dioxolane-acid cluster (6) is necessary to allow the last step Mumm rearrangement which results in the final product. The described mechanism is shown in Scheme 3, with acid counterpart represented as $\boldsymbol{\alpha}$-hydrazino acid.

Maeda et al. found that the rate-determining step is the rearrangement of the $\mathrm{H}$-bonded imidate-acid cluster into the dioxolane-acid cluster (step 5, framed on Scheme 3). ${ }^{27}$ The calculated activation energy needed for this process was 51.8 $\mathrm{kJ} \mathrm{mol}^{-1}$ (at M06/6-31+G(d,p) + ZPE level of theory) with formic acid, formaldehyde and methyl isocyanide as reactants. Implicit model of solvation (PCM-M06/6-31+G(d,p)) in dichloromethane was used to estimate the influence of solvent to the energy profile of the reaction. The solvent effect was very mild, lowering energy barrier of the rate-determining step to $49.8 \mathrm{~kJ} \mathrm{~mol}^{-1}$. In more recent work by Ramozzi and Morokuma, the influence of solvent to the mechanism is additionally studied by DFT. ${ }^{29}$ It was found that in aprotic solvents, the stable nitrilium intermediate could be formed before the occurrence of imidate intermediate. The formation of nitrilium is also catalysed by additional molecule of acid, which means that in aprotic solvent the second (catalytic) molecule

Table 3 Scope of the protocol for the synthesis of hydrazino proline-related depsipeptides ${ }^{a}$
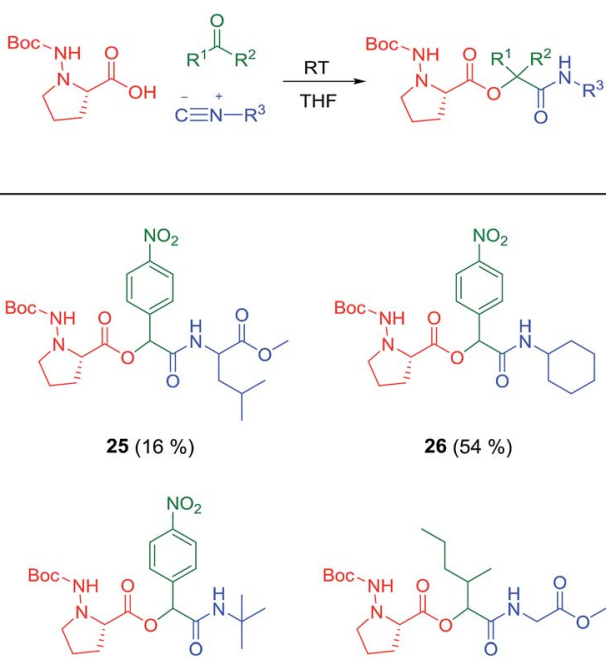

$26(54 \%)$

$27(20 \%)$

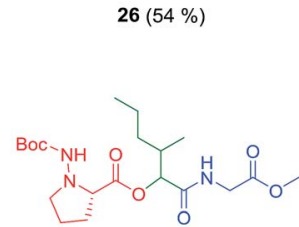

$28(13 \%)$

${ }^{a}$ Isolated yields are given in parentheses. Compounds were isolated as mixture of diastereoisomers. 

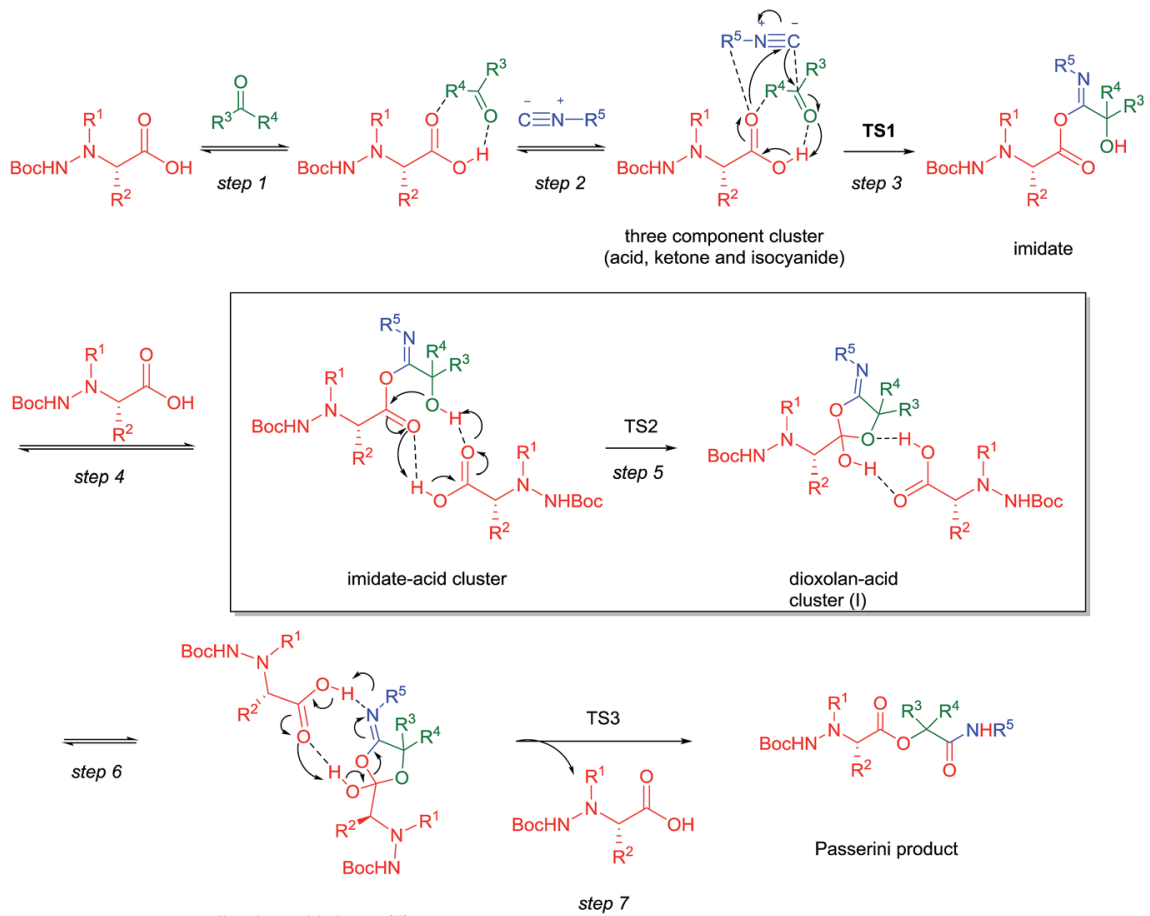

dioxolan-acid cluster (II)

step 7

Scheme 3

of acid enters the mechanism earlier than in the gas phase. The reaction then proceeds into the formation of imidate and rearrangements that lead to the final product. ${ }^{28}$ It is important to note that in this revised mechanism in aprotic solvents, the rate-determining step still remains the same: the transformation of imidate into dioxalane intermediate.

We used DFT approach to calculate the kinetics and thermodynamic equilibrium of the rate-determining step of the Passerini reaction, with some of the reactants used in our work (Scheme 4). The results of computational modeling of the ratedetermining step of the Passerini reaction were compared for two products with profound difference in yield, $\mathbf{1 1}(74 \%)$, and $14(24 \%)$, Table 2 . Two products differentiate only in $\alpha$-hydrazino acid used in the synthesis, $N^{\alpha}$-benzyl, $N^{\beta}$-Boc protected hydrazino phenylanine (type I) for $\mathbf{1 1}$ and $N^{\alpha}$-Boc, $N^{\beta}$-Boc protected hydrazino phenylanine (type II) for 14. Since the only difference between these two sets of reactants was the protective group on $N^{\alpha}$ atom of hydrazino phenylalanine $\left(\mathrm{R}^{1}\right.$, Schemes 3 and 4), we estimated that it is safe to employ smaller model molecules as carbonyl species and isocyanide, for the sake of computational feasibility. Specifically, instead of 2-methylpentanal the formaldehyde was used, and methyl isocyanide was utilized in place of 2-isocyano-3-methyl-methylbutanoate. One additional simplification was the replacement of the protective group on $N^{\beta}$ atom of hydrazino acid; tert-butyloxycarbonyl (Boc) by methoxycarbonyl group (Moc), as shown in Scheme 4.

Geometries of all stationary points (two minima and transition state) were optimized at the M06-2X28/6-31+G(d,p) level of theory. Vibrational analysis was performed to confirm the nature of each stationary point $\left(N_{\text {Imag }}=0\right.$ for minima and $N_{\text {Imag }}$ $=1$ for transition structure) and, in case of transition state, the single imaginary mode was confirmed to correspond to the reaction path that connects two minima. All energies were

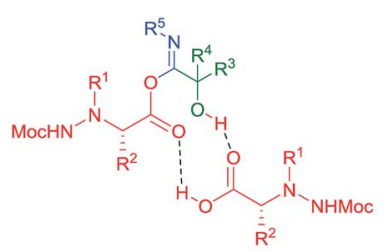

imidate-acid cluster
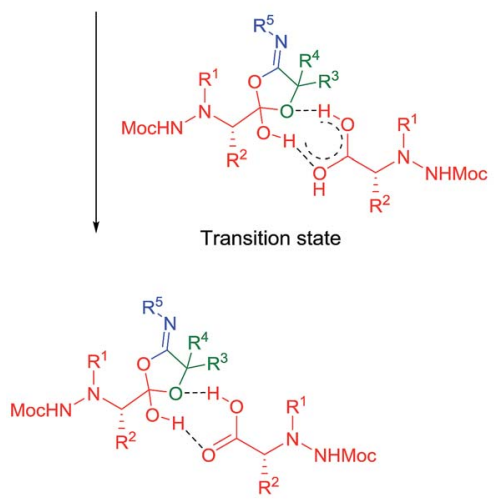

dioxolan-acid cluster (I)

$\mathbf{R}^{1}=$ Bn or Boc; $\mathrm{R}^{2}=-\mathrm{CH}_{2} \mathrm{C}_{6} \mathrm{H}_{5} ; \mathrm{R}^{3}=\mathrm{R}^{4}=-\mathrm{H} ; \mathrm{R}^{5}=-\mathrm{CH}_{3}$ 
corrected for zero point vibrational energy (ZPE). Additionally, to be able to compare our results with those obtained by Maeda et $a .^{27}$ we had to calculate the same process using Maeda's reactants at the same level of theory applied in our work. Results were presented in Table 4. Calculated activation energies for the modelled reaction step are almost the same for all three analysed systems, as well as the thermodynamical equilibria between the two minima. Obviously, the disparity in product yield is not consequence of a different kinetics for this critical step of a reaction.

However, if hydrazino acids are used instead of formic acid, imidate-acid cluster (Scheme 4) may undergo conformational changes that induce formation of alternative $\mathrm{H}$-bonds between additional acid molecule (which serves as a catalyst for this reaction step) and the cluster. Alternative H-bonds stabilize these non-productive conformations of cluster with imidate, so the reaction step from Scheme 4 cannot occur, and reaction does not proceed. Structures of productive conformations of imidate-acid cluster are shown in Fig. 1 , for $N^{\alpha}$-benzyl, $N^{\beta}$-Moc protected hydrazino phenylanine (left) and $N^{\alpha}$-Boc, $N^{\beta}$-Moc protected hydrazino phenylanine (right).

Non-productive conformers of imidate-acid cluster are schematically also presented in Fig. 1. Two types of nonproductive conformers of imidate cluster are identified when hydrazino acid with $\mathrm{R}^{1}$ = benzyl is used, while three nonproductive conformations of imidate cluster are possible for the hydrazino acid with $\mathrm{R}^{1}=$ Boc. This third conformer is result of H-bond formation between the carbonyl oxygen on Boc and hydrogen from carboxylic group of acid. Obviously, in system when benzyl group is present instead of Boc at $N^{\alpha}$ atom, this additional H-bond cannot occur.

To rationalize a difference in yield for Passerini reaction when using hydrazino acid with $\mathrm{R}^{1}=$ benzyl and $\mathrm{R}^{1}=$ Boc, respectively, we compared thermodynamical stability of nonproductive conformers with productive imidate cluster, for systems containing former and latter acid. Results are shown in Table 5. It turned out that non-productive minima for hydrazino acid where $\mathrm{R}^{1}=$ benzyl are only slightly more stable when compared to the productive conformation of imidate cluster $\left(\sim 10 \mathrm{~kJ} \mathrm{~mol}^{-1}\right)$. Given that the whole reaction is relatively fast, that means that only small part of reactants finish in nonproductive conformations. On the other side, two of three existing non-productive minima for system with $\mathrm{R}^{1}=$ Boc show significant stability when compared with productive conformation of imidate cluster $\left(\sim 50-60 \mathrm{~kJ} \mathrm{~mol}^{-1}\right)$. The occurrence of very stable non-productive conformations of imidate cluster

Table 4 Energy profile of reaction step presented in Scheme 4, calculated at M06-2X/6-31+G(d,p) + ZPEM06-2X/6-31+G(d,p) level of theory (in $\mathrm{kJ} \mathrm{mol}^{-1}$ ). First minima formed by clustering imidate and hydrazino acid is taken as a reference point

\begin{tabular}{llll}
\hline & Imidate-acid cluster & TS & Dioxolan-acid cluster \\
\hline $\mathrm{R}^{1}=\mathrm{Bn}$ & 0 & 35.2 & -13.1 \\
$\mathrm{R}^{1}=$ Boc & 0 & 33.0 & -18.2 \\
Maeda's reactants $^{27}$ & 0 & 37.3 & -17.6
\end{tabular}

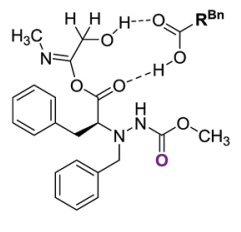

productive

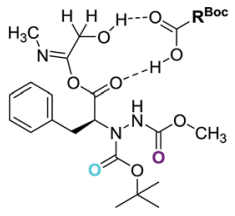

productive

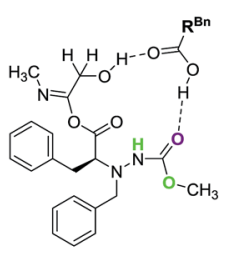

non-productive 1

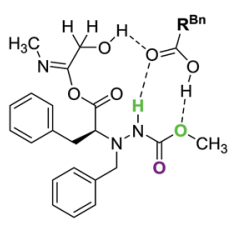

non-productive 2

non-productive 3

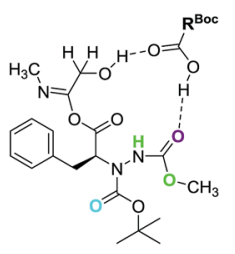

non-productive 1

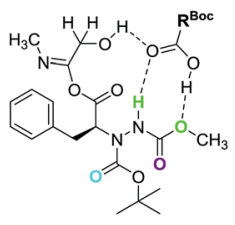

non-productive 2

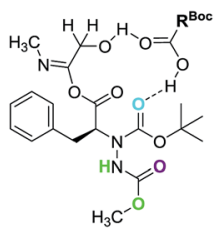

non-productive 3
Fig. 1 Schematic representation of productive and non-productive conformations of imidate-acid cluster with $N^{\alpha}$-benzyl, $N^{\beta}$-Moc protected hydrazino phenylanine (left) and $N^{\alpha}$-Boc, $N^{\beta}$-Moc protected hydrazino phenylanine (right). For the sake of simplicity, the structure of additional hydrazino acid is presented in abbreviated form, whereas the structure of the acid molecule covalently bound to the isocyanide and aldehyde is explicitly drawn.

implies that the rearrangement of imidate to dioxolan which leads to the final product is then impeded. The data from Table 2 indicate that all products with $\mathrm{R}^{1}=$ Boc come with relatively low yield, in a range from 10 to $24 \%$ (compounds 13-16), which may be rationalized in a same way as in case of the compound 14.

Table 5 Energies of non-productive conformers of imidate cluster compared with energies of productive conformation for reactions when hydrazino acid with $\mathrm{R}^{1}=$ benzyl and $\mathrm{R}^{1}=\mathrm{Boc}$ are used (in $\mathrm{kJ}$ $\left.\mathrm{mol}^{-1}\right)$, calculated at M06-2X/6-31+G(d,p) + ZPE $\mathrm{M06}_{\mathrm{M}-2 \mathrm{X} / 6-31+G(\mathrm{~d}, \mathrm{p})}$ level of theory

Non-productive Non-productive Non-productive

Productive 112

\begin{tabular}{lllll}
\hline $\mathrm{R}^{1}=$ Bn & 0 & -11.9 & -10.2 & Non-existent \\
$\mathrm{R}^{1}=$ Boc & 0 & -6.4 & -50.5 & -61.3
\end{tabular}


Presence of additional functionalities in MCR products offers diverse post-condensation modifications affording new, structurally advanced scaffolds. Passerini-amine deprotectionacyl migration (PADAM) is the most exploited post-Passerini protocol used for conversion of depsipeptides into $\alpha$-oxoamides, structural motifs found in natural products and synthetic anticancer compounds and protease inhibitors. ${ }^{15 b, 17 b, 26,30,31} \mathrm{Next}$, diverse protocols were developed toward medium-sized cyclic and macrocyclic compounds, including ring-closing metathesis (RCM), macrolactonizations, click chemistry approaches and MCR-based cyclization. ${ }^{\mathbf{1 5 b}}$ In our particular case, transformation of linear hydrazino depsipeptides into their cyclic analogous would be attractive additional benefit of new peptidomimetic structures. As a proof-ofprinciple, we chose $N^{\alpha}$-benzyl, $N^{\beta}$-Boc-protected derivative 1 bearing methyl ester group at C-terminal position. Two-step deprotection procedure, base conditions for the removal of ester group followed by acid-promoted Boc cleavage, yielded unprotected hydrazino depsipeptide that was subjected to intramolecular cyclization in the presence of HATU coupling reagent, under pseudo-diluted conditions (Scheme 5). After HPLC purification cyclic hydrazino depsipeptide 29 was isolated in $15 \%$ yield.

Recently, a decarboxylative multicomponent reactions of $\alpha$ amino acid (proline) with various aldehydes and isocyanides yielding $\mathrm{N}$-substituted proline amides were performed under metal-free conditions. ${ }^{32}$ Reaction is based on thermal decarboxylation of in situ formed imine to form azomethine ylide, which undergoes nucleophilic insertion of isocyanide, followed by hydrolysis to furnish $N$-substituted proline amides. We speculated that in a similar manner, $N^{\alpha}$-unsubstituted hydrazino acids could yield $N^{\alpha}$-substituted amides. Therefore, a test reaction was performed under conditions found optimal for the decarboxylative multicomponent coupling with proline. ${ }^{32} \mathrm{~A}$ reaction of $N^{\beta}$-Boc-protected hydrazino-L-phenylalanine, $p$-nitro benzaldehyde and cyclohexyl isocyanide gave cyclohexyl amide of the $N^{\alpha}$-substituted hydrazino acid 30 (Scheme 6 ) in $20 \%$ yield.

Therefore, this procedure could be used for the synthesis of various $N^{\alpha}$-substituted derivatives of hydrazino acids, but further development requires optimization of decarboxylative multicomponent reaction for hydrazino acids. Finally, $N^{\alpha}$ unsubstituted hydrazino acids can be exploited as bifunctional reagents in MCRs. While reaction performed under reaction conditions optimized for Passerini reaction gave no product, the same reactants in methanol after $24 \mathrm{~h}$ yielded Ugi-type of highly branched $N^{\alpha}$-substituted hydrazino derivative 31 in 25\%

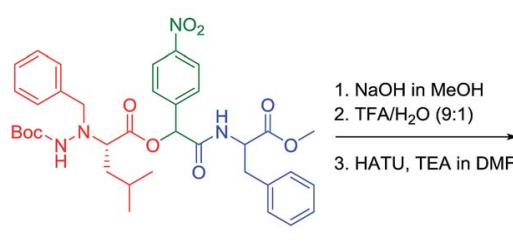

1

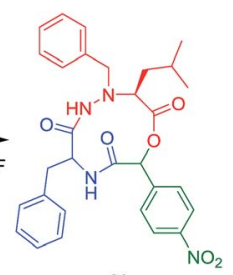

29

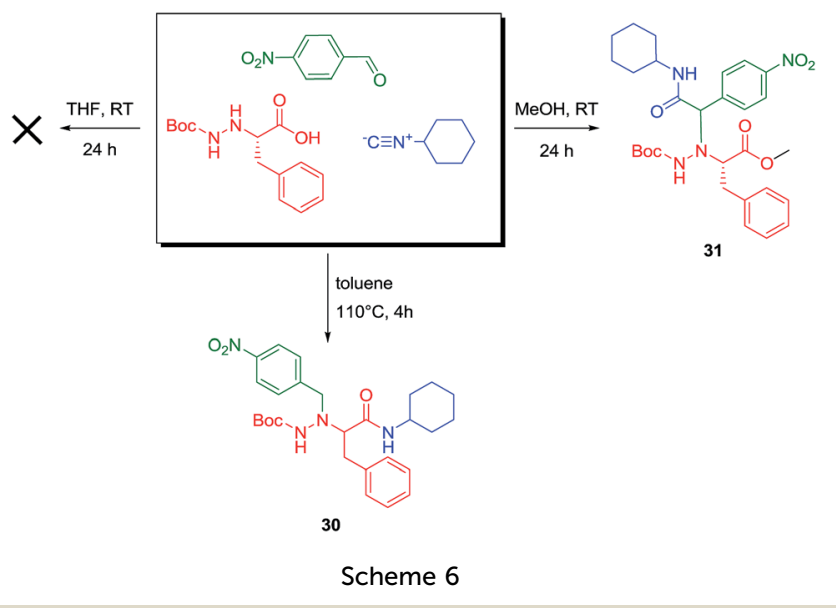

yield (Scheme 6). So, our current efforts are directed toward further exploring the utility of hydrazino acids in other MCRs. Also, based on here proved methodology, we plan to develop a focused library of hydrazino depsipeptides, to probe interactions with nucleic acids and proteins.

\section{Conclusions}

We have developed methodology for the synthesis of new class of peptidomimetics - hydrazino depsipeptides, by multicomponent reaction of an $\alpha$-hydrazino acid, an aldehyde or ketone and an isocyanide component. $\alpha$-Hydrazino acids bearing different protecting groups at $N^{\alpha}$ were used to allow further specific modification of Passerini products. $N^{\alpha}$-Benzyl, $N^{\beta}$-Boc protected hydrazino acids gave hydrazino depsipeptides in considerably better yields then their $N^{\alpha}$-Boc and $N^{\alpha}$-Cbzprotecting analogues. This finding was rationalized by DFT calculations showing that significant stability of two nonproductive conformations of imidate intermediate in the ratedetermining step of the reaction hinders rearrangement into dioxolan intermediate which leads to the Passerini product.

\section{Experimental section}

\section{General method}

All experiments were monitored by analytical thin layer chromatography (TLC) performed on Merck Kieselgel $60 \mathrm{~F}_{254} 0.25$ $\mathrm{mm}$ precoated aluminium plates. After elution, plate was visualized under UV illumination at $254 \mathrm{~nm}$ for UV active materials. Further visualization was achieved by staining with ammonium molybdate and charring on a hot plate. Flash column chromatography was performed on silica gel (Merck, 40-63 $\mu \mathrm{m}$ particle size) by standard techniques eluting with solvents as indicated. ${ }^{1} \mathrm{H}$ NMR and ${ }^{13} \mathrm{C}$ NMR spectra were recorded on Bruker Avance $600 \mathrm{MHz}$ and $300 \mathrm{MHz}$ spectrometers, operating at 150.92 or $75.47 \mathrm{MHz}$ for ${ }^{13} \mathrm{C}$ and 600.13 or $300.13 \mathrm{MHz}$ for ${ }^{1} \mathrm{H}$ nuclei. Chemical shifts are quoted in ppm, and tetramethylsilane (TMS) was used as internal standard. Spectra were acquired at 298 K. Mass spectrometry measurements were performed on a triple quadrupole mass spectrometer, operating in a positive 
electrospray ionization (ESI) mode. High resolution mass spectrometry (HRMS) was performed on a nanoUPLC-ESI-qTOF in positive and negative mode. Racemic amino acid-derived isocyanides were prepared according to procedure published by Zhu and Danishesky. ${ }^{33}$

\section{General procedure}

To a glass vial containing $1 \mathrm{M}$ solution of oxo-compound $(0.11$ mmol) in THF under nitrogen were added $N^{\alpha}, N^{\beta}$-protected hydrazino acid $(0.11 \mathrm{mmol})$ and the isocyanide $(0.11 \mathrm{mmol})$. With all reactants added, the solution was allowed to stir for either $24 \mathrm{~h}$ in reactions with aldehydes or $48 \mathrm{~h}$ in reactions with ketones. The reactions were concentrated under reduced pressure and reaction mixtures were purified by flash column chromatography using petrol ether/ethyl acetate $2: 1$. Products were isolated and characterized as mixture of diastereoisomers.

tert-Butyl 2-benzyl-2-((2S)-1-(2-((1-methoxy-1-oxo-3-phenylpropan-2-yl)amino)-1-(4-nitrophenyl)-2-oxoethoxy)-4-methyl-1-oxopentan-2-yl)hydrazine-1-carboxylate (1). Yield: $54 \%$ (40 mg); yellow oil; $R_{\mathrm{f}}=0.5$ (petrol ether/ethyl acetate $2: 1, \mathrm{v} / \mathrm{v}$ ); ${ }^{1} \mathrm{H}$ NMR $\left(\mathrm{CDCl}_{3}\right): \delta 0.71-0.91(\mathrm{~m}, 6 \mathrm{H}), 1.26-1.58(\mathrm{~m}, 12 \mathrm{H}), 3.15-3.25(\mathrm{~m}$, $3 \mathrm{H}), 3.72-3.81(\mathrm{~m}, 2 \mathrm{H}), 3.83(\mathrm{~s}, 3 \mathrm{H}), 4.75-4.79(\mathrm{~m}, 1 \mathrm{H}), 6.05-6.16$ (m, 1H), 7.27-7.40 (m, 10H), 8.07 (d, J=8.7 Hz, 2H), 8.18-8.25 $(\mathrm{m}, 2 \mathrm{H}), 8.39(\mathrm{~d}, J=8.6 \mathrm{~Hz}, 2 \mathrm{H}) .{ }^{13} \mathrm{C} \mathrm{NMR}\left(\mathrm{CDCl}_{3}\right): \delta 20.4,21.4$, $21.5,22.0,22.30,23.9,24.0,24.3,27.5,27.7,38.4,38.5,40.8$, $41.1,41.3,50.2,51.8,52.7,54.0,54.6,60.1,75.7,76.3,81.2$, $127.0,127.1,127.4,127.9,128.2$, 128.3, 128.5, 128.7, 128.9, 129.1, 129.3, 129.4, 136.5, 159.8, 167.1, 171.7. MS (ESI+): $\mathrm{m} / z=$ 677.6. HRMS: calcd for $\mathrm{C}_{36} \mathrm{H}_{45} \mathrm{~N}_{4} \mathrm{O}_{9}[\mathrm{M}+\mathrm{H}]^{+}$677.3187; found 677.3184 .

tert-Butyl 2-benzyl-2-((2S)-1-(2-(1-methoxy-1-oxo-3-phenylpropan-2-ylamino)-1-(4-nitrophenyl)-2-oxoethoxy)-3-methyl-1-oxobutan-2-yl)hydrazinecarboxylate (2). Yield: 63\% (37 mg); yellow oil; $R_{\mathrm{f}}=0.6$ (petrol ether/ethyl acetate $2: 1, \mathrm{v} / \mathrm{v}$ ). ${ }^{1} \mathrm{H}$ NMR $\left(\mathrm{CDCl}_{3}\right)$ : $\delta$ 0.71-0.89 (m, 3H), 1.01-1.13 (m, 3H), 1.32-1.46 (m, $9 \mathrm{H}), 1.98-2.14(\mathrm{~m}, 1 \mathrm{H}), 3.00-3.27(\mathrm{~m}, 3 \mathrm{H}), 3.72-4.10(\mathrm{~m}, 5 \mathrm{H})$, 4.88-4.98 (m, 1H), 6.04-6.19 (m, 1H), 6.69-6.80 (m, 2H), 7.05$768(\mathrm{~m}, 12 \mathrm{H}), 8.16-8.25(\mathrm{~m}, 2 \mathrm{H}) .{ }^{13} \mathrm{C} \mathrm{NMR}\left(\mathrm{CDCl}_{3}\right): \delta 18.4,18.8$, 19.1, 27.1, 27.7, 28.1, 29.2, 34.9, 36.0, 52.0, 52.1, 52.3, 52.5, 52.6, 52.8, 66.8, 70.7, 73.8, 74.0, 80.0, 123.4, 123.8, 126.8, 127.1, 127.4, $127.8,128.2$, 128.4, 128.5, 128.6, 128.9, 129.2, 129.3, 129.4, 130.0, 134.7, 136.0, 136.3, 141.4, 147.8, 166.0, 170.8, 170.9. MS (ESI+): $m / z=663.5$. HRMS: calcd for $\mathrm{C}_{35} \mathrm{H}_{43} \mathrm{~N}_{4} \mathrm{O}_{9}[\mathrm{M}+\mathrm{H}]^{+}$ 663.3030; found 663.3036.

tert-Butyl 2-benzyl-2-((2R)-1-(1-(1-methoxy-3-methyl-1-oxobutan2-ylamino)-3-methyl-1-oxohexan-2-yloxy)-3-methyl-1-oxobutan2-yl)hydrazinecarboxylate (3). Yield: $21 \%$ (12 mg); yellow oil; $R_{\mathrm{f}}$ $=0.7$ (petrol ether/ethyl acetate $2: 1, \mathrm{v} / \mathrm{v}) .{ }^{1} \mathrm{H}$ NMR $\left(\mathrm{CDCl}_{3}\right)$ : $\delta$ 0.91-1.05 (m, 18H), 1.13-1.40 (m, 13H), 2.05-2.35 (m, 3H), 3.10-3.45 (m, 1H), 3.58-4.05 (m, 5H), 4.55-4.70 (m, 1H), 4.80$5.20(\mathrm{~m}, 1 \mathrm{H}), 7.27-7.68(\mathrm{~m}, 7 \mathrm{H}) .{ }^{13} \mathrm{C} \mathrm{NMR}\left(\mathrm{CDCl}_{3}\right): \delta 13.4,13.5$, 13.6, 13.9, 14.1 14.5, 14.6, 16.2, 16.6, 17.3, 17.5, 17.8, 19.0, 19.2, 19.7, 19.9, 27.6, 27.8, 28.1, 28.2, 30.8, 31.4, 32.6, 36.0, 52.2, 52.4, $57.1,57.3,65.7,78.3$, 78.9, 87.2, 127.0, 127.6, 128.5, 128.9, 129.2, 129.4, 137.0, 154.9, 156.6, 171.9, 177.0, 178.2. MS (ESI+): $m / z=$
564.4. HRMS: calcd for $\mathrm{C}_{30} \mathrm{H}_{50} \mathrm{~N}_{3} \mathrm{O}_{7}[\mathrm{M}+\mathrm{H}]^{+}$564.3649; found 564,3649 .

tert-Butyl 2-benzyl-2-((2R)-1-(1-(tert-butylamino)-3-methyl-1oxohexan-2-yloxy)-3-methyl-1-oxobutan-2-yl)hydrazinecarboxylate (4). Yield: $29 \%$ (18 mg); yellow oil; $R_{\mathrm{f}}=0.75$ (petrol ether/ethyl acetate $2: 1, \mathrm{v} / \mathrm{v}) .{ }^{1} \mathrm{H}$ NMR $\left(\mathrm{CDCl}_{3}\right): \delta 0.88-0.94(\mathrm{~m}, 15 \mathrm{H}), 1.30-$ 1.37 (m, 19H), 2.05-2.10 (m, 1H), 2.48-2.52 (m, 1H), 3.15-3.35 (m, $1 \mathrm{H}), 3.75-4.15(\mathrm{~m}, 2 \mathrm{H}), 4.75-5.10(\mathrm{~m}, 1 \mathrm{H}), 5.65-5.75$ (br s, $1 \mathrm{H})$, 6.75-7.75 (m, 7H). ${ }^{13} \mathrm{C} \mathrm{NMR}\left(\mathrm{CDCl}_{3}\right): \delta 13.6,16.3,19.3,19.9,27.7$, 28.16, 28.22, 33.6, 34.9, 35.5, 38.1, 65.7, 66.2, 68.3, 78.3, 78.9, 87.4, 127.0, 127.7, 131.4, 147.7, 161.9, 170.7, 172.2. MS (ESI+): $m / z=$ 506.4. ESI-HRMS: calcd for $\mathrm{C}_{28} \mathrm{H}_{48} \mathrm{~N}_{3} \mathrm{O}_{5}[\mathrm{M}+\mathrm{H}]^{+}$506.3594; found 506.3594 .

tert-Butyl 2-benzyl-2-((2S)-1-(2-(1-methoxy-1-oxo-3-phenylpropan-2-ylamino)-1-(4-nitrophenyl)-2-oxoethoxy)-1-oxopropan-2-yl)hydrazinecarboxylate (5). Yield: $59 \%(41 \mathrm{mg})$; yellow oil; $R_{\mathrm{f}}=$ 0.45 (petrol ether/ethyl acetate $2: 1, \mathrm{v} / \mathrm{v}) ;{ }^{1} \mathrm{H}$ NMR $\left(\mathrm{CDCl}_{3}\right)$ : $\delta$ 1.32-1.41 (m, 12H), 3.03-3.30 (m, 2H), 3.68-3.80 (m, 4H), 3.85-4.05 (m, 2H), 4.79-4.94 (m, 1H), 6.13-6.20 (m, 1H), 6.25$6.40(\mathrm{~m}, 1 \mathrm{H}), 6.80-7.60(\mathrm{~m}, 13 \mathrm{H}), 8.14-8.23(\mathrm{~m}, 2 \mathrm{H}) .{ }^{13} \mathrm{C} \mathrm{NMR}$ $\left(\mathrm{CDCl}_{3}\right): \delta 18.4,18.8,19.1,19.4,27.1,27.7,28.2,29.2,34.9,36.7$, 37.0, 38.4, 52.0, 52.1, 52.3, 52.5, 52.6, 52.8, 66.8, 70.7, 73.8, 74.0, $79.4,123.4,123.8,126.8,127.1,127.2,127.8,128.1,128.3,128.4$, 128.6, 128.9, 129.3, 129.2, 129.4, 134.7, 136.0, 136.3, 141.3, 147.8, 166.0, 171.6, 171.9. MS (ESI+): $m / z=635.4$. HRMS: calcd for $\mathrm{C}_{33} \mathrm{H}_{39} \mathrm{~N}_{4} \mathrm{O}_{9}[\mathrm{M}+\mathrm{H}]^{+}$635.2717; found 635.2716.

tert-Butyl 2-benzyl-2-((2S)-1-(2-(1-methoxy-4-methyl-1-oxopentan-2-ylamino)-2-oxo-1-phenylethoxy)-4-methyl-1-oxopentan-2-yl)hydrazinecarboxylate (6). Yield: $22 \%(17 \mathrm{mg})$; yellow oil; $R_{\mathrm{f}}=0.6$ (petrol ether/ethyl acetate $2: 1, \mathrm{v} / \mathrm{v}) .{ }^{1} \mathrm{H} \mathrm{NMR}\left(\mathrm{CDCl}_{3}\right): \delta 0.85-$ 0.98 (m, 12H), 1.49-1.57 (m, 11H), 1.66-1.78 (m, 4H), 3.58-3.80 $(\mathrm{m}, 5 \mathrm{H}), 3.84-4.20(\mathrm{~m}, 2 \mathrm{H}), 4.55-4.67(\mathrm{~m}, 1 \mathrm{H}), 5.25-5.55(\mathrm{~m}$, $1 \mathrm{H}), 6.10-6.40(\mathrm{~m}, 1 \mathrm{H}), 7.30-8.20(\mathrm{~m}, 12 \mathrm{H}) .{ }^{13} \mathrm{C} \mathrm{NMR}\left(\mathrm{CDCl}_{3}\right)$ : $\delta 21.1,22.2,24.4,27.5,27.7,27.8,29.2,36.1,38.2,41.1,41.3$, 50.2 , 50.3, 51.9, 52.2, 53.0, 54.0, 58.6, 60.1, 62.6, 75.0, 75.36, 75.41, 79.2, 80.9, 126.8, 127.0, 127.2, 127.7, 128.1, 128.2, 128.4, 128.5, 128.8, 129.1, 129.3, 129.8, 133.1, 133.2, 137.9, 140.7, 164.3, 164.4, 167.3. MS (ESI+): $m / z=598.5$. HRMS: calcd for $\mathrm{C}_{33} \mathrm{H}_{48} \mathrm{~N}_{3} \mathrm{O}_{7}[\mathrm{M}+\mathrm{H}]^{+}$598.3492; found 598.3486.

tert-Butyl 2-benzyl-2-((2S)-1-(1-(1-methoxy-4-methyl-1-oxopentan-2-ylamino)-2-methyl-1-oxopropan-2-yloxy)-4-methyl-1-oxopentan-2-yl)hydrazinecarboxylate (7). Yield: $42 \%$ (30 mg); yellow oil; $R_{\mathrm{f}}=0.7$ (petrol ether/ethyl acetate $\left.2: 1, \mathrm{v} / \mathrm{v}\right) .{ }^{1} \mathrm{H}$ NMR $\left(\mathrm{CDCl}_{3}\right)$ : $\delta$ 0.96-1.01 (m, 12H), 1.32-1.43 (m, 5H), 1.50-1.63 (m, 12H), 1.67-1.77 (m, 2H), 1.80-1.95 (m, 2H), $3.74(\mathrm{~s}, 3 \mathrm{H}), 3.78(\mathrm{~s}, 2 \mathrm{H})$, 3.85-4.10 (m, 1H), 4.20-4.32, (m, 1H), 4.55-4.80 (m, 1H), 7.30$7.45(\mathrm{~m}, 7 \mathrm{H}) .{ }^{13} \mathrm{C} \mathrm{NMR}\left(\mathrm{CDCl}_{3}\right): \delta 20.4,21.4,21.5,22.0,22.4$, 24.0, 24.3, 27.5, 27.7, 27.8, 38.4, 38.5, 40.8, 41.1, 41.3, 48.8, 50.2, 50.3, 51.8, 52.3, 52.7, 54.1, 54.6, 58.6, 60.1, 67.1, 75.7, 81.3, $127.0,127.4,127.7,127.8,128.0,128.5,129.0,129.2$, 131.1, 136.6, 160.0, 168.8, 171.8. MS (ESI+): $m / z=550.6$. HRMS: calcd for $\mathrm{C}_{29} \mathrm{H}_{48} \mathrm{~N}_{3} \mathrm{O}_{7}[\mathrm{M}+\mathrm{H}]^{+} 550.3492$, found 550.3491 .

tert-Butyl 2-benzyl-2-((2S)-1-(2-(cyclohexylamino)-1-(4-nitrophenyl)-2-oxoethoxy)-1-oxo-3-phenylpropan-2-yl)hydrazinecarboxylate (9). Yield: $36 \%$ (25 mg); yellow oil; $R_{\mathrm{f}}=0.4$ (petrol ether/ethyl acetate $2: 1, \mathrm{v} / \mathrm{v}) .{ }^{1} \mathrm{H}$ NMR $\left(\mathrm{CDCl}_{3}\right): \delta 1.27-1.60(\mathrm{~m}$, $19 \mathrm{H}), 2.95-3.25$ (m, 2H), 3.55-4.15 (m, 4H), 4.80-5.20 (m, 1H), 
5.85-6.18 (m, 1H), 7.20-7.35 (m, 6H), 8.05-8.11 (m, 4H), 8.36$8.44(\mathrm{~m}, 5 \mathrm{H}) .{ }^{13} \mathrm{C} \mathrm{NMR}\left(75 \mathrm{MHz}, \mathrm{CDCl}_{3}\right) \delta 24.3,24.8,24.9,27.5$, 27.7, 29.2, 32.2, 32.3, 35.4, 48.3, 66.9, 74.2, 74.3, 74.6, 83.0, $123.3,123.8,126.3,127.3,127.7,127.8,127.9$, 128.1, 128.3, 128.5, 128.6, 128.8, 129.3, 130.0, 133.6, 139.4, 170.1, 170.2. MS (ESI+): $m / z=631.3$. HRMS: calcd for $\mathrm{C}_{35} \mathrm{H}_{43} \mathrm{~N}_{4} \mathrm{O}_{7}[\mathrm{M}+\mathrm{H}]^{+}$ 631.3132; found 631.3134.

tert-Butyl 2-benzyl-2-((2S)-1-(1-(1-methoxy-3-methyl-1-oxobutan2-ylamino)-3-methyl-1-oxohexan-2-yloxy)-1-oxo-3-phenylpropan2-yl)hydrazinecarboxylate (11). Yield: 74\% (64 mg); yellow oil; $R_{\mathrm{f}}$ $=0.65$ (petrol ether/ethyl acetate $2: 1, \mathrm{v} / \mathrm{v}) .{ }^{1} \mathrm{H}$ NMR $\left(\mathrm{CDCl}_{3}\right)$ : $\delta 0.92(\mathrm{~d}, J=6.9 \mathrm{~Hz}, 6 \mathrm{H}), 0.96(\mathrm{~d}, J=6.9 \mathrm{~Hz}, 6 \mathrm{H}), 1.40-1.46(\mathrm{~m}$, $4 \mathrm{H}), 1.52$ (s, 9H), 2.20-2.25 (m, 2H), 2.30-2.35 (m, 3H), 3.70-3.73 $(\mathrm{m}, 5 \mathrm{H}), 4.23(\mathrm{~s}, 3 \mathrm{H}), 4.53-4.61(\mathrm{~m}, 1 \mathrm{H}), 4.63-4.70(\mathrm{~m}, 1 \mathrm{H}), 7.17-$ $7.38(\mathrm{~m}, 10 \mathrm{H}), 8.30$ (br s, $1 \mathrm{H}), 8.92(\mathrm{~d}, 1 \mathrm{H}) .{ }^{13} \mathrm{C} \mathrm{NMR}\left(\mathrm{CDCl}_{3}\right)$ : $\delta 16.8,17.8,17.9,19.1,19.4,20.3,28.1,28.3,31.4,31.5,33.7$, $34.0,52.4,53.3,55.8,56.7,63.0,63.1,78.2,78.6,83.9,126.7$, $127.6,128.2$, 128.3, 128.5, 128.9, 129.3, 129.5, 129.8, 160.7, 167.0, 172.2. MS (ESI+): $m / z=612.6$. ESI-HRMS: calcd for $\mathrm{C}_{34} \mathrm{H}_{50} \mathrm{~N}_{3} \mathrm{O}_{7}[\mathrm{M}+\mathrm{H}]^{+}$612.3649; found 612.3646.

tert-Butyl 2-benzyl-2-((2S)-1-(1-(2-methoxy-2-oxoethylamino)3-methyl-1-oxohexan-2-yloxy)-1-oxo-3-phenylpropan-2-yl)hydrazinecarboxylate (12). Yield: $32 \%(26 \mathrm{mg})$, yellow oil; $R_{\mathrm{f}}=0.46$ (petrol ether/ethyl acetate $2: 1, \mathrm{v} / \mathrm{v}) .{ }^{1} \mathrm{H}$ NMR $\left(\mathrm{CDCl}_{3}\right): \delta 0.84-$ 0.91 (m, 6H), 1.30-1.50 (m, 13H), 3.10-3.18 (m, 1H), 3.58-3.80 (m, 4H), 3.85-4.20 (m, 3H), 4.35-4.60 (br s, 1H), 5.11-5.28 (m, 1H), 6.45-6.75 (m, 1H), 7.05-7.42 (m, 8H), 7.45-8.15 (m, 3H). ${ }^{13} \mathrm{C} \mathrm{NMR}\left(\mathrm{CDCl}_{3}\right): \delta 13.6,13.8,19.7,27.7,28.2,32.8,35.1,35.8$, 40.4, 46.3, 52.3, 60.8, 78.1, 79.8, 83.7, 127.8, 128.2, 128.4, 128.5, 128.8, 130.5, 133.2, 148.1, 176.6, 178.5, 180.9. MS (ESI+): $\mathrm{m} / z=$ 570.3. ESI-HRMS: calcd for $\mathrm{C}_{31} \mathrm{H}_{44} \mathrm{~N}_{3} \mathrm{O}_{7}[\mathrm{M}+\mathrm{H}]^{+}$570.3179; found 570.3173 .

Di-tert-butyl 1-((2S)-1-(2-(1-methoxy-1-oxo-3-phenylpropan-2ylamino)-1-(4-nitrophenyl)-2-oxoethoxy)-4-methyl-1-oxopentan2-yl)hydrazine-1,2-dicarboxylate (13). Yield: 17\% (13 mg); colorless oil; $R_{\mathrm{f}}=0.45$ (petrol ether/ethyl acetate $2: 1, \mathrm{v} / \mathrm{v}$ ). ${ }^{1} \mathrm{H}$ NMR $\left(\mathrm{CDCl}_{3}\right): \delta$ 0.90-0.95 (m, 6H), 1.48-1.52 (m, 20H), 1.731.85 (m, 2H), 3.02-3.19 (m, 3H), 3.71-3.79 (m, 3H), 4.75-4.96 (m, 2H), 6.09-6.15 (br s, 1H), 7.15-7.27 (m, 7H), 7.55-7.63 (br s, $1 \mathrm{H}), 8.12-8.25(\mathrm{~m}, 2 \mathrm{H}) .{ }^{13} \mathrm{C} \mathrm{NMR}\left(\mathrm{CDCl}_{3}\right) \delta 21.9,23.1,24.7,28.2$, 28.3, 29.8, 37.3, 37.5, 39.1, 52.6, 53.4, 53.6, 75.3, 82.5, 82.6, $123.9,124.3,127.3,127.8,128.1,128.6,129.2,129.7,130.6$, 148.2, 166.9, 171.4. MS (ESI+): $m / z=687.4$. ESI-HRMS: calcd for $\mathrm{C}_{34} \mathrm{H}_{47} \mathrm{~N}_{4} \mathrm{O}_{11}[\mathrm{M}+\mathrm{H}]^{+}$687.3241; found 687.3237.

Di-tert-butyl 1-((2S)-1-(1-(1-methoxy-3-methyl-1-oxobutan-2ylamino)-3-methyl-1-oxohexan-2-yloxy)-1-oxo-3-phenylpropan-2yl)hydrazine-1,2-dicarboxylate (14). Yield: $24 \%$ (21 mg); colorless oil; $R_{\mathrm{f}}=0.7$ (petrol ether/ethyl acetate $2: 1, \mathrm{v} / \mathrm{v}$ ). ${ }^{1} \mathrm{H}$ NMR $\left(\mathrm{CDCl}_{3}\right): \delta 0.85-0.98(\mathrm{~m}, 8 \mathrm{H}), 1.01(\mathrm{~d}, 3 \mathrm{H}), 1.12(\mathrm{~d}, 3 \mathrm{H}), 1.29-1.55$ (m, 20H), 2.12-2.35 (m, 2H), 3.18-3.32 (m, 2H), $3.82(\mathrm{~s}, 3 \mathrm{H}), 4.17$ $(\mathrm{m}, 1 \mathrm{H}), 4.35-4.55(\mathrm{~m}, 1 \mathrm{H}), 5.02-5.16(\mathrm{~m}, 1 \mathrm{H}), 7.13-7.44(\mathrm{~m}$, $6 \mathrm{H}) .{ }^{13} \mathrm{C} \mathrm{NMR}\left(\mathrm{CDCl}_{3}\right): \delta 13.6,14.8,16.2,18.6,19.6,27.5,27.6$, 29.2, 30.7, 34.2, 34.9, 51.4, 52.6, 56.7, 62.3, 78.7, 126.2, 126.3, 128.0, 128.1, 129.0, 160.1, 166.4, 172.5. MS (ESI+): $\mathrm{m} / z=622.5$. ESI-HRMS: calcd for $\mathrm{C}_{32} \mathrm{H}_{52} \mathrm{~N}_{3} \mathrm{O}_{9}[\mathrm{M}+\mathrm{H}]^{+}$622,3704; found 622.3694 .
Di-tert-butyl 1-((2S)-1-(2-(2-methoxy-2-oxoethylamino)-1-(4nitrophenyl)-2-oxoethoxy)-1-oxo-3-phenylpropan-2-yl)hydrazine1,2-dicarboxylate (15). Yield: $23 \%(20 \mathrm{mg})$; colorless oil; $R_{\mathrm{f}}=0.2$ (petrol ether/ethyl acetate $2: 1, \mathrm{v} / \mathrm{v}) .{ }^{1} \mathrm{H}$ NMR $\left(\mathrm{CDCl}_{3}\right): \delta 1.34-$ $1.50(\mathrm{~m}, 18 \mathrm{H}), 3.08-3.27$ (m, 2H), 3.46 (s, 3H), 3.69 (s, 2H), 3.97$4.12(\mathrm{~m}, 1 \mathrm{H}), 6.02-6.18(\mathrm{~m}, 1 \mathrm{H}), 7.02-7.42(\mathrm{~m}, 6 \mathrm{H}), 7.55-7.75(\mathrm{br}$ $\mathrm{s}, 1 \mathrm{H}), 8.02-8.45(\mathrm{~m}, 4 \mathrm{H}) .{ }^{13} \mathrm{C} \mathrm{NMR}\left(\mathrm{CDCl}_{3}\right): \delta 28.1,29.7,30.2$, 40.7, 50.8, 52.1, 75.2, 75.5, 82.4, 82.6, 123.5, 124.3, 126.6, 127.1, 128.6, 129.0, 129.3, 130.5, 140.1, 142.4, 148.0, 167.8, 169.6, MS $(\mathrm{ESI}+): m / z=631.2$. ESI-HRMS: calcd for $\mathrm{C}_{30} \mathrm{H}_{39} \mathrm{~N}_{4} \mathrm{O}_{11}[\mathrm{M}+\mathrm{H}]^{+}$ 631.2615; found 631.2609.

Di-tert-butyl 1-((2S)-1-(1-(1-methoxy-4-methyl-1-oxopentan-2ylamino)-2-methyl-1-oxopropan-2-yloxy)-1-oxo-3-phenylpropan2-yl)hydrazine-1,2-dicarboxylate (16). Yield: 10\% (8 mg); colorless oil; $R_{\mathrm{f}}=0.42$ (petrol ether/ethyl acetate $\left.2: 1, \mathrm{v} / \mathrm{v}\right) .{ }^{1} \mathrm{H}$ NMR $\left(\mathrm{CDCl}_{3}\right): \delta 0.91-0.96(\mathrm{~m}, 6 \mathrm{H}), 1.32-1.48(\mathrm{~m}, 20 \mathrm{H}), 1.57-1.66(\mathrm{~m}$, 7H), 3.05-3.19 (m, 2H), 3.55-3.69 (br s, 3H), 4.35-4.73 (m, 2H), 7.20-7.35 (m, 7H). ${ }^{13} \mathrm{C} \mathrm{NMR}\left(\mathrm{CDCl}_{3}\right): \delta 21.2,22.1,22.4,22.9$, 24.3 , 27.5, 27.6, 37.4, 50.0, 50.3, 51.2, 51.5, 81.4, 82.2, 126.4, 127.3, 127.8, 128.3, 128.6, 129.0, 167.2, 173.0. MS (ESI+): $m / z=$ 594.5. ESI-HRMS: calcd for $\mathrm{C}_{30} \mathrm{H}_{48} \mathrm{~N}_{3} \mathrm{O}_{9}[\mathrm{M}+\mathrm{H}]^{+}$594.3391; found 594.3384.

1-Benzyl 2-tert-butyl 1-((2S)-1-(2-(1-methoxy-1-oxo-3-phenylpropan-2-ylamino)-1-(4-nitrophenyl)-2-oxoethoxy)-4-methyl-1oxopentan-2-yl)hydrazine-1,2-dicarboxylate (17). Yield: 11\% (9 $\mathrm{mg}$ ); colorless oil; $R_{\mathrm{f}}=0.43$ (petrol ether/ethyl acetate $2: 1, \mathrm{v} / \mathrm{v}$ ). ${ }^{1} \mathrm{H}$ NMR $\left(\mathrm{CDCl}_{3}\right): \delta 0.80-0.98(\mathrm{~m}, 6 \mathrm{H}), 1.50-1.65(\mathrm{br} \mathrm{s}, 20 \mathrm{H})$, 3.01-3.29 (m, 2H), 3.55-3.75 (m, 3H), 4.65-4.79 (m, 2H), 5.07$5.28(\mathrm{~m}, 2 \mathrm{H}), 5.95-6.25(\mathrm{~m}, 1 \mathrm{H}), 7.25-7.40$ (m, 12H), 7.75-8.40 $(\mathrm{m}, 4 \mathrm{H}) .{ }^{13} \mathrm{C} \mathrm{NMR}\left(\mathrm{CDCl}_{3}\right): \delta 21.7,23.0,24.4,28.4,35.3,39.0$, 53.6, 59.2, 65.6, 68.9, 72.3, 124.1, 124.5, 127.1, 127.7, 129.4, 129.5, 129.7, 130.6, 131.1, 141.0, 156.9, 169.1, 170.8, 171.5. MS (ESI+): $m / z=721.6$. ESI-HRMS: calcd for $\mathrm{C}_{37} \mathrm{H}_{45} \mathrm{~N}_{4} \mathrm{O}_{11}[\mathrm{M}+\mathrm{H}]^{+}$ 721.3085; found 721.3076.

1-Benzyl 2-tert-butyl 1-((2S)-1-(2-(cyclohexylamino)-1-(4nitrophenyl)-2-oxoethoxy)-4-methyl-1-oxopentan-2-yl)hydrazine1,2-dicarboxylate (18). Yield: 55\% (39 mg); colorless oil; $R_{\mathrm{f}}=$ 0.45 (petrol ether/ethyl acetate $2: 1, \mathrm{v} / \mathrm{v}) .{ }^{1} \mathrm{H} \mathrm{NMR}\left(\mathrm{CDCl}_{3}\right)$ $\delta$ 0.75-2.15 (m, 26H), 3.76 (br s, 1H), 5.15-5.25 (m, 1H), 6.95$6.20(\mathrm{~m}, 1 \mathrm{H}), 7.29-7.33(\mathrm{~m}, 5 \mathrm{H}), 7.55-7.63$ (m, 2H), 8.10-8.25 $(\mathrm{m}, 2 \mathrm{H}) .{ }^{13} \mathrm{C} \mathrm{NMR}\left(\mathrm{CDCl}_{3}\right) \delta 22.9,24.8$ 25.4, 28.0, 29.4, 32.6, 32.8, 35.0, 48.7, 57.9, 65.4, 71.1, 85.3, 123.7, 127.0, 127.7, 128.6, 130.5, 139.3, 140.1, 140.9, 150.2, 151.2, 169.2, 170.6, 171.2 MS (ESI+): $m / z=641.2$. ESI-HRMS: calcd for $\mathrm{C}_{33} \mathrm{H}_{45} \mathrm{~N}_{4} \mathrm{O}_{9}[\mathrm{M}+\mathrm{H}]^{+}$ 641.3187; found 641.3187.

1-Benzyl 2-tert-butyl 1-((2S)-1-(1-(cyclohexylamino)-3-methyl1-oxohexan-2-yloxy)-4-methyl-1-oxopentan-2-yl)hydrazine-1,2dicarboxylate (19). Yield: $27 \%(29 \mathrm{mg})$; colorless oil; $R_{\mathrm{f}}=0.43$ (petrol ether/ethyl acetate $2: 1, \mathrm{v} / \mathrm{v}) .{ }^{1} \mathrm{H} \mathrm{NMR}\left(\mathrm{CDCl}_{3}\right): \delta 0.63-$ 1.15 (m, 12H), 1.16-1.25 (m, 6H), 1.30-1.42 (m, 6H), 1.55-1.62 $(\mathrm{m}, 3 \mathrm{H}), 1.65-1.75(\mathrm{~m}, 4 \mathrm{H}), 1.80-1.90(\mathrm{~m}, 3 \mathrm{H}), 3.70-3.85(\mathrm{~m}$, 2H), 5.05-5.20 (m, 2H), $5.73(\mathrm{~m}, 1 \mathrm{H}), 7.19-7.23(\mathrm{~m}, 5 \mathrm{H}) .{ }^{13} \mathrm{C}$ NMR $\left(\mathrm{CDCl}_{3}\right): \delta 13.6,15.1,19.6,20.4,24.3,25.0,27.5,32.5,32.6$, 33.1, 34.6, 34.7, 47.4, 68.0, 74.1, 76.4, 78.0, 127.8, 128.1, 128.7, 142.1, 167.6, 168.0, 169.1, 169.2. MS (ESI+): $m / z=590.6$. HRMS: calcd for $\mathrm{C}_{32} \mathrm{H}_{52} \mathrm{~N}_{3} \mathrm{O}_{7}[\mathrm{M}+\mathrm{H}]^{+} 590.3805$; found for 590.3805 . 
1-Benzyl 2-tert-butyl 1-((2S)-1-(1-(tert-butylamino)-3-methyl1-oxohexan-2-yloxy)-4-methyl-1-oxopentan-2-yl)hydrazine-1,2dicarboxylate (20). Yield: $32 \%(20 \mathrm{mg})$; colorless oil; $R_{\mathrm{f}}=0.36$ (petrol ether/ethyl acetate $2: 1, \mathrm{v} / \mathrm{v}) .{ }^{1} \mathrm{H}$ NMR $\left(300 \mathrm{MHz}, \mathrm{CDCl}_{3}\right)$ $\delta$ 0.79-1.85 (m, 25H), 4.60-4.75 (m, 3H), $5.21(\mathrm{br} \mathrm{s}, 1 \mathrm{H}), 7.25-$ $7.42(\mathrm{~m}, 7 \mathrm{H}) .{ }^{13} \mathrm{C} \mathrm{NMR}\left(\mathrm{CDCl}_{3}\right): \delta 13.5,13.6,13.7,14.5,14.6$, 19.6, 24.0, 27.6, 28.1, 29.2, 34.6, 42.2, 61.3, 64.9, 67.8, 80.6, 88.6, 127.9, 128.0, 128.1, 137.1, 153.8, 155.4, 169.4, 172.3. MS (ESI+): $m / z=$ 564.4. ESI-HRMS: calcd for $\mathrm{C}_{30} \mathrm{H}_{50} \mathrm{~N}_{3} \mathrm{O}_{7}[\mathrm{M}+\mathrm{H}]^{+}$ 564.3649; found 564.3647.

1-Benzyl 2-tert-butyl 1-((2S)-1-(1-(1-methoxy-3-methyl-1oxobutan-2-ylamino)-3-methyl-1-oxohexan-2-yloxy)-1-oxo-3phenylpropan-2-yl)hydrazine-1,2-dicarboxylate (21). Yield: $54 \%$ $\left(50 \mathrm{mg}\right.$ ); colorless oil; $R_{\mathrm{f}}=0.46$ (petrol ether/ethyl acetate $2: 1$, $\mathrm{v} / \mathrm{v}) .{ }^{1} \mathrm{H}$ NMR $\left(\mathrm{CDCl}_{3}\right) \delta 0.66-0.82(\mathrm{~m}, 12 \mathrm{H}), 1.10-1.55(\mathrm{~m}, 13 \mathrm{H})$, 1.84 (br s, $1 \mathrm{H}), 2.09$ (br s, $1 \mathrm{H}), 3.12-3.30(\mathrm{~m}, 2 \mathrm{H}), 3.53-3.65(\mathrm{~m}$, $3 \mathrm{H}), 4.43(\mathrm{br} \mathrm{s}, 1 \mathrm{H}), 4.68(\mathrm{~s}, 2 \mathrm{H}), 5.12-5.25(\mathrm{~m}, 2 \mathrm{H}), 7.14-7.24$ $(\mathrm{m}, 11 \mathrm{H}) .{ }^{13} \mathrm{C}$ NMR $\left(\mathrm{CDCl}_{3}\right) \delta 14.0,14.1,15.3,18.1,19.0,20.1$, 20.2, 28.0, 30.7, 34.9, 52.0, 57.2, 65.3, 68.5, 78.6, 81.6, 127.0, 127.6, 128.0, 128.5, 128.6, 128.7, 135.6, 141.0, 155.7, 156.0, 169.2, 169.8, 172.0. MS (ESI + ): $m / z=656.4$. ESI-HRMS: calcd for $\mathrm{C}_{35} \mathrm{H}_{50} \mathrm{~N}_{3} \mathrm{O}_{9}[\mathrm{M}+\mathrm{H}]^{+}$656.3547; found 656.3544.

1-Benzyl 2-tert-butyl 1-((2S)-1-(1-(tert-butylamino)-3-methyl1-oxohexan-2-yloxy)-1-oxo-3-phenylpropan-2-yl)hydrazine-1,2dicarboxylate (22). Yield: $43 \%(28 \mathrm{mg})$; colorless oil; $R_{\mathrm{f}}=0.57$ (petrol ether/ethyl acetate $2: 1, \mathrm{v} / \mathrm{v}) .{ }^{1} \mathrm{H}$ NMR $\left(\mathrm{CDCl}_{3}\right) \delta 0.77-$ $0.88(\mathrm{~m}, 4 \mathrm{H}), 1.20-1.50(\mathrm{~m}, 20 \mathrm{H}), 1.55-1.85(\mathrm{~m}, 5 \mathrm{H}), 3.03-3.30$ (m, 2H), 4.55-4.70 (m, 2H), 5.09-5.25 (m, 2H), 7.16-7.43 (m, 12H). ${ }^{13} \mathrm{C}$ NMR $\left(\mathrm{CDCl}_{3}\right) \delta$ 14.0, 14.1, 20.1, 28.5, 28.6, 29.7, 34.9, 35.2, 35.7, 51.4, 65.3, 68.5, 82.1, 127.0, 127.6, 128.7, 128.8, 140.9, 154.4, 155.2, 168.5, 169.2. MS (ESI+): $m / z=598.5$. ESI-HRMS: calcd for $\mathrm{C}_{33} \mathrm{H}_{48} \mathrm{~N}_{3} \mathrm{O}_{7}[\mathrm{M}+\mathrm{H}]^{+}$598.3492; found 598.3489.

1-Benzyl 2-tert-butyl 1-((2S)-1-(2-(2-methoxy-2-oxoethylamino)1-(4-nitrophenyl)-2-oxoethoxy)-1-oxo-3-phenylpropan-2-yl)hydrazine-1,2-dicarboxylate (23). Yield: $32 \%$ (30 mg); colorless oil; $R_{\mathrm{f}}$ $=0.17$ (petrol ether/ethyl acetate $2: 1, \mathrm{v} / \mathrm{v}) .{ }^{1} \mathrm{H}$ NMR $\left(\mathrm{CDCl}_{3}\right)$ $\delta$ 1.25-1.45 (s, 9H), 3.15-3.30 (m, 2H), 3.55-4.18 (m, 6H), 5.12$5.25(\mathrm{~m}, 2 \mathrm{H}), 6.04-6.20(\mathrm{br} \mathrm{s}, 1 \mathrm{H}), 7.10-7.60(\mathrm{~m}, 10 \mathrm{H}), 7.50-7.60$ (m, 2H), 8.00-8.20 (m, 2H). ${ }^{13} \mathrm{C}$ NMR $\left(75 \mathrm{MHz}, \mathrm{CDCl}_{3}\right) \delta 28.1$, 29.8, 40.9, 52.3, 67.0, 68.6, 73.7, 82.6, 123.6, 123.7, 126.9, 127.0, $127.3,127.8,128.1,128.6,128.7,128.8,129.1,129.2,136.3$, $136.7,142.2,146.8,148.2,155.1,167.7,169.7,169.9,171.2$. MS (ESI+): $m / z=665.3$. ESI-HRMS: calcd for $\mathrm{C}_{33} \mathrm{H}_{37} \mathrm{~N}_{4} \mathrm{O}_{11}[\mathrm{M}+\mathrm{H}]^{+}$ 665.2459; found for 665.2458.

(2S)-2-(1-Methoxy-4-methyl-1-oxopentan-2-ylamino)-1-(4-nitrophenyl)-2-oxoethyl 1-(tert-butoxycarbonylamino) pyrrolidine-2carboxylate (25). Yield: $16 \%(11 \mathrm{mg})$; yellow oil; $R_{\mathrm{f}}=0.47$ (petrol ether/ethyl acetate $2: 1, \mathrm{v} / \mathrm{v}) .{ }^{1} \mathrm{H}$ NMR $\left(\mathrm{CDCl}_{3}\right): \delta 0.88-$ $0.97(\mathrm{~m}, 6 \mathrm{H}), 1.49(\mathrm{~s}, 9 \mathrm{H}), 1.62-1.78(\mathrm{~m}, 4 \mathrm{H}), 1.82-2.10(\mathrm{~m}, 4 \mathrm{H})$, 3.75-2.95 (m, 1H), 3.25-3.80 (m, 1H), 3.67-3.75 (m, 3H), 3.80$3.92(\mathrm{~m}, 1 \mathrm{H}), 4.60-4.71(\mathrm{~m}, 1 \mathrm{H}), 5.35-5.55(\mathrm{~m}, 2 \mathrm{H}), 6.19(\mathrm{~s}$, 1H),7.20-7.45 (m, 2H), 7.64-7.74 (m, 2H), 8.12-8.45 (m, 3H). ${ }^{13} \mathrm{C}$ $\operatorname{NMR}\left(\mathrm{CDCl}_{3}\right): \delta 21.6,21.8,22.7,22.8,22.9,24.2,24.7,24.9,28.2$, 28.4, 40.6, 40.8, 40.9, 45.8, 46.7, 50.7, 52.3, 52.5, 64.0, 74.6, 74.9, 78.0, 78.3, 78.6, 81.3, 81.5, 123.8, 124.3, 127.9, 129.0, 130.5, 142.4, 148.2, 155.6, 167.1, 171.7, 172.6. MS (ESI+): $m / z=422.2$.
ESI-HRMS: calcd for $\mathrm{C}_{20} \mathrm{H}_{26} \mathrm{~N}_{3} \mathrm{O}_{7}[\mathrm{M}-\mathrm{BocNH}-\mathrm{H}]^{-} 420.1771$; found 420.1778 .

(2S)-2-(Cyclohexylamino)-1-(4-nitrophenyl)-2-oxoethyl 1(tert-butoxycarbonylamino) pyrrolidine-2-carboxylate (26). Yield: $54 \%$ ( $48 \mathrm{mg}$ ); orange oil; $R_{\mathrm{f}}=0.4$ (petrol ether/ethyl acetate $2: 1, \mathrm{v} / \mathrm{v}) .{ }^{1} \mathrm{H}$ NMR $\left(\mathrm{CDCl}_{3}\right) \delta 1.20-1.40(\mathrm{~m}, 5 \mathrm{H}), 1.52-$ $1.96(\mathrm{~m}, 20 \mathrm{H}), 2.70-2.78(\mathrm{~m}, 1 \mathrm{H}), 3.16-3.29(\mathrm{~m}, 1 \mathrm{H}), 3.74-3.88$ $(\mathrm{m}, 2 \mathrm{H}), 5.30-5.70(\mathrm{~m}, 2 \mathrm{H}), 6.13(\mathrm{~s}, 1 \mathrm{H}), 6.92-7.05(\mathrm{~m}, 1 \mathrm{H})$, 7.66-7.72 (m, $2 \mathrm{H}), 8.20-8.25(\mathrm{~m}, 2 \mathrm{H}) .{ }^{13} \mathrm{C} \mathrm{NMR}\left(\mathrm{CDCl}_{3}\right): \delta 24.3$, 24.7, 25.1, 25.4, 27.5, 28.2, 28.3, 32.7, 32.8, 45.8, 48.6, 48.7, $63.1,64.1,74.8,75.1,78.0,81.4,81.5,123.7,123.8,124.3$, 128.0, 128.7, 130.5, 142.9, 148.1, 155.7, 155.8, 166.0, 166.1, 170.6, 171.4. MS (ESI + ): $m / z=376.3$. ESI-HRMS: calcd for $\mathrm{C}_{24} \mathrm{H}_{33} \mathrm{~N}_{4} \mathrm{O}_{7}[\mathrm{M}-\mathrm{H}]^{-}$489.2349; found 489.2336.

(2S)-2-(tert-Butylamino)-1-(4-nitrophenyl)-2-oxoethyl 1-(tertbutoxycarbonylamino) pyrrolidine-2-carboxylate (27). Yield: $20 \%$ (12 mg); colorless oil; $R_{\mathrm{f}}=0.45$ (petrol ether/ethyl acetate $2: 1, \mathrm{v} / \mathrm{v}) .{ }^{1} \mathrm{H} \mathrm{NMR}\left(\mathrm{CDCl}_{3}\right): \delta 1.39(\mathrm{~s}, 9 \mathrm{H}), 1.49(\mathrm{~s}, 9 \mathrm{H}), 1.96-2.15$ (m, $4 \mathrm{H}), 2.88-2.95(\mathrm{br} \mathrm{s}, 1 \mathrm{H}), 3.20-3.28(\mathrm{br} \mathrm{s}, 1 \mathrm{H}), 3.93-4.05(\mathrm{~m}$, $1 \mathrm{H}), 5.45-5.57(\mathrm{~m}, 2 \mathrm{H}), 6.04(\mathrm{~s}, 1 \mathrm{H}), 6.55(\mathrm{br} \mathrm{s}, 1 \mathrm{H}), 7.64(\mathrm{~d}, J=$ $8.7 \mathrm{~Hz}, 2 \mathrm{H}), 8.21(\mathrm{~d}, J=8.8 \mathrm{~Hz}, 2 \mathrm{H}) .{ }^{13} \mathrm{C}$ NMR $\left(\mathrm{CDCl}_{3}\right) \delta 24.7$, 24.9, 28.2, 28.5, 28.6, 28.7, 29.7, 46.2, 46.8, 52.0, 64.3, 64.5, 74.7, 75.3, 81.2, 81.3, 123.8, 124.1, 124.3, 127.1, 128.0, 128.4, 130.5, 143.0, 143.1, 148.0, 155.5, 166.1, 166.2, 171.1, 171.5. MS (ESI+): $m / z=350.1$. ESI-HRMS: calcd for $\mathrm{C}_{17} \mathrm{H}_{22} \mathrm{~N}_{3} \mathrm{O}_{5}[\mathrm{M}-\mathrm{BocNH}-$ $\mathrm{H}]^{-}$348.1559; found 348.1559.

(2S)-1-(2-Methoxy-2-oxoethylamino)-3-methyl-1-oxohexan-2-yl 1-(tert-butoxycarbonylamino) pyrrolidine-2-carboxylate (28). Yield: $13 \%\left(12 \mathrm{mg}\right.$ ); colorless oil; $R_{\mathrm{f}}=0.3$ (petrol ether/ethyl acetate $2: 1, \mathrm{v} / \mathrm{v}) .{ }^{1} \mathrm{H}$ NMR $\left(\mathrm{CDCl}_{3}\right): \delta 0.87-0.90(\mathrm{~m}, 3 \mathrm{H}), 0.90-$ $0.98(\mathrm{~m}, 3 \mathrm{H}), 1.46-1.50(\mathrm{~m}, 11 \mathrm{H}), 1.8-2.20(\mathrm{~m}, 6 \mathrm{H}), 2.65-2.80$ (m, 1H), 3.20-3.30 (m, 1H), 3.80-4.25 (m, 3H), 5.25, $5.33(\mathrm{~m}$, $1 \mathrm{H}), 5.75-5.80(\mathrm{~m}, 1 \mathrm{H}), 7.25-7.50(\mathrm{br} \mathrm{s}, 1 \mathrm{H}) .{ }^{13} \mathrm{C} \mathrm{NMR}\left(\mathrm{CDCl}_{3}\right)$ $\delta$ 14.1, 14.2, 15.5, 15.8, 20.1, 20.2, 20.3, 23.3, 24.3, 28.1, 28.2, 28.5, 34.9, 35.1, 35.5, 25.6, 40.7, 46.8, 52.0, 52.1, 52.5, 63.5, 63.7, 63.8, 63.9, 67.0, 78.2, 78.3, 78.4, 81.3, 81.4, 81.5, 155.7, 155.8, 156.1, 156.2, 160.9, 169.6, 169.7, 169.9, 170.1, 170.3, 171.6, 171.8, 172.2. ESI-HRMS: calcd for $\mathrm{C}_{20} \mathrm{H}_{34} \mathrm{~N}_{3} \mathrm{O}_{7}[\mathrm{M}-\mathrm{H}]^{-}$ 428.2397; found 428.2389 .

Synthesis of (3S)-4,7-dibenzyl-3-isobutyl-10-(4-nitrophenyl)1,4,5,8-oxatriazecane-2,6,9-trione (29). Passerini product 5 (40 $\mathrm{mg} ; 0.063 \mathrm{mmol}$ ) was dissolved in $\mathrm{MeOH}$ and $1 \mathrm{M} \mathrm{NaOH}$ (126 $\mu \mathrm{L}, 0.13 \mathrm{mmol}$ ) was added. Reaction was stirred under reflux and followed by TLC (petrol ether/ethyl acetate $2: 1, \mathrm{v} / \mathrm{v}$ ). After $1 \mathrm{~h}$, solvent was evaporated, residue dissolved in water, $\mathrm{pH}$ adjusted to 3 by citric acid and product extracted with EtOAc. Crude product was dissolved in TFA- $\mathrm{H}_{2} \mathrm{O}(9: 1, \mathrm{v} /$ $\mathrm{v}, 1 \mathrm{~mL}$ ), reaction was stirred at room temperature $1 \mathrm{~h}$ and then product precipitated with di-isopropyl ether. Crude product $(22 \mathrm{mg}, 0.042 \mathrm{mmol})$ and TEA $(6 \mu \mathrm{L} ; 0.042 \mathrm{mmol})$ were dissolved in dry DMF $(12 \mathrm{~mL})$, and the solution was added dropwise via a syringe pump (flow rate $0.8 \mathrm{~mL} \mathrm{~h}^{-1}$ ) into the solution of HATU ( $36 \mathrm{mg} ; 0.092 \mathrm{mmol})$ and TEA $(6 \mu \mathrm{L}$; $0.042 \mathrm{mmol})$ in dry DMF $(2 \mathrm{~mL})$. The solvent was diluted with water, product extracted with ether, washed with brine and water and purified by HPLC. Yield: $15 \%$ ( $4.5 \mathrm{mg})$; colourless oil; $T_{\mathrm{R}}=26.7 \mathrm{~min}(\mathrm{C}-18 \mathrm{RP}$ HPLC column $(150 \times 4.5 \mathrm{~mm}$, ID 5 
$\mu \mathrm{m})$, liner gradient from $30 \% \mathrm{MeOH}$ to $90 \% \mathrm{MeOH}$ in $60 \mathrm{~min}$; $\lambda 254 \mathrm{~nm}) .{ }^{1} \mathrm{H}$ NMR (600 MHz, $\left.\mathrm{CDCl}_{3}\right): \delta 1.30-1.60(\mathrm{~m}, 6 \mathrm{H})$, $2.25(\mathrm{~m}, 1 \mathrm{H}), 3.25-3.20(\mathrm{~m}, 4 \mathrm{H}), 3.55-3.65(\mathrm{~m}, 2 \mathrm{H}), 4.15-4.20$ (m, 1H), 4.75-4.80 (m, 1H), 4.95-5.05 (m, 1H), 7.15-7.25 (m, $5 \mathrm{H}), 7.30-7.45(\mathrm{~m}, 7 \mathrm{H}), 7.95-8.10(\mathrm{~m}, 1 \mathrm{H}), 8.25-8.35(\mathrm{~m}, 2 \mathrm{H})$, 8.40-8.50 (m, 1H). ${ }^{13} \mathrm{C}$ NMR (151 MHz, $\left.\mathrm{CDCl}_{3}\right): \delta$ 13.9, 21.7, 29.6, 37.7, 51.5, 53.1, 57.4, 64.8, 68.6, 86.7, 122.3, 123.4, $123.6,125.8,126.7,127.7,128.2$, 128.7, 128.8, 129.2, 129.3, 130.9, 131.2, 132.2, 135.1, 139.7, 147.7, 169.1, 171.5, 173.9. ESI-HRMS: calcd for $\mathrm{C}_{27} \mathrm{H}_{27} \mathrm{~N}_{4} \mathrm{O}_{6}[\mathrm{M}+\mathrm{H}]^{+}$503.1931; found 503.1928.

Synthesis of tert-butyl 2-(1-(cyclohexylamino)-1-oxo-3phenylpropan-2-yl)-2-(4-nitrobenzyl)hydrazinecarboxylate (30). To a glass vial containing $1 \mathrm{M}$ solution of $p$-nitro benzaldehyde (21 $\mathrm{mg}, 0.14 \mathrm{mmol}$ ) in dry toluene under nitrogen were added $N^{\beta}$-Boc-L-hPhe-OH $(50 \mathrm{mg}, 0.18 \mathrm{mmol}$ ) and cyclohexyl isocyanide $(22 \mu \mathrm{L}, 0.18 \mathrm{mmol})$. Reaction was stirring for $4 \mathrm{~h}$ under reflux $\left(110^{\circ} \mathrm{C}\right)$. The reactions were concentrated under reduced pressure and reaction mixtures were purified by flash column chromatography using petrol ether/ethyl acetate $2: 1$. Yield: $20 \%$ (18 mg); yellow oil; $R_{\mathrm{f}}=0.32$ (petrol ether/ethyl acetate $2: 1, \mathrm{v} / \mathrm{v}) .{ }^{1} \mathrm{H}$ NMR $\left(600 \mathrm{MHz}, \mathrm{CDCl}_{3}\right): \delta 1.30-1.45(\mathrm{~m}, 17 \mathrm{H})$, 2.95-3.20 (m, 2H), 3.30-3.80 (m, 3H), 4.10 (br s, 1H), 4.20-4.40 (br s, 1H), 5.85-6.10 (br s, 1H), 7.15-7.20 (m, 2H), 7.30-7.45 (m, $2 \mathrm{H}), 7.55-7.80(\mathrm{~m}, 2 \mathrm{H}), 8.10-8.30(\mathrm{~m}, 4 \mathrm{H}) .{ }^{13} \mathrm{C}$ NMR $(151 \mathrm{MHz}$, $\left.\mathrm{CDCl}_{3}\right): \delta 24.9,25.4,25.7,28.0,28.1,28.2,28.3,29.7,32.5,48.3$, 48.7, 55.3, 65.3, 83.5, 123.6, 124.0, 127.6, 128.3, 128.8, 129.0, 129.3, 129.5, 155.7, 165,4, 168.0. MS (ESI+): $m / z=497.1$. ESIHRMS: calcd for $\mathrm{C}_{27} \mathrm{H}_{35} \mathrm{~N}_{4} \mathrm{O}_{5}[\mathrm{M}-\mathrm{H}]^{-}$495.2607; found 495.2609.

Synthesis of tert-butyl 2-(2-(cyclohexylamino)-1-(4-nitrophenyl)-2-oxoethyl)-2-((S)-1-methoxy-1-oxo-3-phenylpropan-2-yl) hydrazinecarboxylate (31). To a glass vial containing $1 \mathrm{M}$ solution of $p$-nitro benzaldehyde $(16.5 \mathrm{mg}, 0.11 \mathrm{mmol})$ in $\mathrm{MeOH}$ under nitrogen were added $N^{\beta}$-Boc-L-hPhe-OH $(31 \mathrm{mg}, 0.11$ $\mathrm{mmol})$ and the isocyanide $(13 \mu \mathrm{L}, 0.11 \mathrm{mmol})$, and solution was allowed to stir for $24 \mathrm{~h}$. The reaction was concentrated under reduced pressure and reaction mixture was purified by flash column chromatography using petrol ether/ethyl acetate $2: 1$. Yield (14 mg; 25\%); brown oil; $R_{\mathrm{f}}=0.57$ (petrol ether/ethyl acetate $2: 1, \mathrm{v} / \mathrm{v}) .{ }^{1} \mathrm{H}$ NMR $\left(600 \mathrm{MHz}, \mathrm{CDCl}_{3}\right): \delta 1.34(\mathrm{~s}, 9 \mathrm{H})$, 1.55-1.80 (m, 10H), 2.95-3.05 (m, 2H), 3.55-3.65 (m, 1H), 3.72 (s, 3H), 3.75-3.85 (m, 1H), 4.55-4.70 (br s, 1H), 7.25-7.36 (m, $5 \mathrm{H})$, 7.55-7.70 (m, 2H), 8.8.05-8.15 (br s, $1 \mathrm{H}), 8.20-8.25$ (m, 2H). ${ }^{13} \mathrm{C}$ NMR (151 MHz, $\left.\mathrm{CDCl}_{3}\right): \delta 24.2,24.3,24.4,24.9,27.6,27.9$, 31.6, 31.8, 32.4, 36.1, 42.0, 43.0, 47.9, 48.0, 51.5, 51.8, 53.0, 69.0, $72.6,73.5,74.3,80.2,80.8,122.8,123.1,123.4,126.5,126.8$, $128.0,128.3,129.0,130.4,136.9,141.3,147.4,155.6,167.9$, 173.0. MS (ESI +$): m / z=555$. ESI-HRMS: calcd for $\mathrm{C}_{29} \mathrm{H}_{39} \mathrm{~N}_{4} \mathrm{O}_{7}[\mathrm{M}$ $+\mathrm{H}]^{+}$555.2819; found 555.2820.

\section{Acknowledgements}

We thank the Croatian Science Foundation, Grant number 3102 for financial support and the University of Zagreb Computing Centre (SRCE) for granting computational time on ISABELLA cluster.

\section{Notes and references}

1 A. Barker, J. G. Kettle, T. Nowak and J. E. Pease, Drug Discovery Today, 2013, 18, 298.

2 D. J. Newman and G. M. Cragg, J. Nat. Prod., 2012, 75, 311.

3 M. Dow, M. Fisher, T. James, F. Marchetti and A. Nelson, Org. Chem. Biochem., 2012, 10, 17.

4 L. M. Blair and J. Sperry, J. Nat. Prod., 2013, 76, 794.

5 M. Hamada, T. Takeuchi, S. Kondo, Y. Ikeda, H. Naganawa, K. Maeda, Y. Okami and H. Umezawa, J. Antibiot., 1970, 23, 170.

6 H. J. Klosterman, G. L. Lamoureux and J. L. Parsons, Biochemistry, 1967, 6, 170.

7 A. J. Oelke, D. J. France, T. Hofmann, G. Wuitschik and S. V. Ley, Nat. Prod. Rep., 2011, 28, 1445.

8 I. Avan, C. D. Hallb and A. R. Katritzky, Chem. Soc. Rev., 2014, 43, 3575.

9 M. Laurencin, B. Legrand, E. Duval, J. Henry, M. BaudyFloc'h, C. Zatylny-Gaudin and A. Bondon, J. Med. Chem., 2012, 55, 2025.

10 (a) A. Bordessa, M. Keita, X. Maréchal, L. Formicola, N. Lagarde, J. Rodrigoa, G. Bernadat, C. Bauvais, J. L. Soulier, L. Dufau, T. Milcent, B. Crousse, M. ReboudRavauxb and S. Ongeri, Eur. J. Med. Chem., 2013, 70, 505; (b) S. Aubin, B. Martin, J.-G. Delcros, Y. Arlot-Bonnemains and M. Baudy-Floc'h, J. Med. Chem., 2005, 48, 330.

11 A. Altmayer-Henzien, V. Declerck, J. Farjon, D. Merlet, R. Guillot and D. J. Aitken, Angew. Chem., Int. Ed., 2015, 54, 10807.

12 R.-O. Moussodia, S. Acherar, E. Romero, C. Didierjean and B. Jamart-Gregoire, J. Org. Chem., 2015, 80, 3022.

13 J. Suć, L.-M. Tumir, L. Glavaš-Obrovac, M. Jukić, I. Piantanida and I. Jerić, Org. Biomol. Chem., 2016, 14, 4865.

14 (a) B. Ganem, Acc. Chem. Res., 2010, 42, 463; (b) C. de Graaff, E. Ruijter and R. V. A. Orru, Chem. Soc. Rev., 2012, 41, 3969; (c) S. Brauch, S. S. van Berkel and B. Westermann, Chem. Soc. Rev., 2013, 42, 4948.

15 (a) P. Slobbe, E. Ruijter and R. V. A. Orru, Med. Chem. Commun., 2012, 3, 1189; (b) A. Dömling, W. Wang and K. Wang, Chem. Rev., 2012, 112, 3083.

16 (a) C. M. Madsen and M. H. Clausen, Eur. J. Org. Chem., 2011, 3107; (b) D. G. Rivera, F. León, O. Concepción, F. E. Morales and L. A. Wessjohann, Chem.-Eur. J., 2013, 19, 6417.

17 (a) A. D. F. S. Barreto, O. E. Vercillo, L. A. Wessjohann and C. K. Z. Andrade, Beilstein J. Org. Chem., 2014, 10, 1017; (b) G. Koopmanschap, E. Ruijter and R. V. Orru, Beilstein J. Org. Chem., 2014, 10, 544.

18 M. Pelay-Gimeno, J. Tulla-Puche and F. Albericio, Mar. Drugs, 2013, 11, 1693.

19 R. Lemmens-Gruber, M. R. Kamyar and R. Dornetshuber, Curr. Med. Chem., 2009, 16, 1122.

20 Y. K. Feng, J. A. Lu, M. Behl and A. Lendlein, Macromol. Biosci., 2010, 10, 1008.

21 (a) L. El Kaïm, M. Gizolme and L. Grimaud, Org. Lett., 2006, 8, 5021; (b) L. El Kaïm, M. Gizolme, L. Grimaud and J. Oble, J. Org. Chem., 2007, 72, 4169; (c) H. Yanai, T. Sakiyama, 
T. Oguchi and T. Taguchi, Tetrahedron Lett., 2012, 53, 3161; (d) H. Yanai, T. Oguchi and T. Taguchi, J. Org. Chem., 2009, 74, 3927; (e) M. Tobisu, A. Kitajima, S. Yoshioka, I. Hyodo, M. Oshita and N. Chatani, J. Am. Chem. Soc., 2007, 129, 11431; $(f)$ T. Soeta, S. Matsuzaki and Y. Ukaji, J. Org. Chem., 2015, 0, 3688.

22 G. Lelais and D. Seebach, Helv. Chim. Acta, 2003, 86, 4152. 23 J. Suć and I. Jerić, SpringerPlus, 2015, 4, 507.

24 D. Bonnet, C. Grandjean, P. Rousselot-Pailley, P. Joly, L. Bourel-Bonnet, V. Santraine, H. Gras-Masse and O. Melnyk, J. Org. Chem., 2003, 68, 7033.

25 T. Bousquet, M. Jida, M. Soueidan, R. Deprez-Poulain, F. Agbossou-Niedercorn and L. Pelinski, Tetrahedron Lett., 2012, 53, 306.
26 A. Dömling, Chem. Rev., 2006, 106, 17.

27 S. Maeda, S. Komagawa, M. Uchiyama and K. Morokuma, Angew. Chem., Int. Ed., 2011, 50, 644.

28 Y. Zhao and D. G. Truhlar, Acc. Chem. Res., 2008, 41, 157.

29 R. Ramozzi and K. Morokuma, J. Org. Chem., 2015, 80, 5652. 30 S. Faure, T. Hjelmgaard, S. P. Roche, D. J. Aitken and V. Uni, Org. Lett., 2009, 11, 1167.

31 L. Banfi, R. Riva and A. Basso, Synlett, 2009, 23.

32 S. Dighe, U. K. S. Anil Kumar, S. Srivastava, P. Shukla, S. Singh, M. Dikshit and S. Batra, J. Org. Chem., 2015, 80, 99. 33 J. Zhu, X. Wu and S. J. Danishefsky, Tetrahedron Lett., 2009, $50,577$. 